\title{
Subsidiarity in International Human Rights Law_-What is Subsidiary about Human Rights?
}

\author{
Samantha Besson*
}

\begin{abstract}
Subsidiarity is en vogue in international human rights law. From a largely implicit and mainly jurisprudential principle used in discrete guises by international human rights courts, it has become increasingly present in human rights reasoning and is about to become entrenched in the text of international human rights treaties. Past the usual truisms about States having the primary responsibility to secure human rights and international human rights institutions having only a supervisory function, however, the notion, role and justification of subsidiarity in international human rights law remain very difficult to capture. Broadly speaking, scholarly strategies have divided into two groups. Most authors focus on one aspect of subsidiarity (usually the margin of appreciation of domestic authorities), while fewer look for the broader underpinning principle. The former often neglect the broader question, however, while the latter have often been lured by one dimension of the prestigious history of the principle of subsidiarity and conflate subsidiarity in international human rights law with one or many of its different conceptions in other legal and political contexts (e.g. in a federal state or in the European Union). In this article, I argue that the concept of subsidiarity is at play in international human rights law, but that human rights subsidiarity is very different from the other conceptions of subsidiarity we know of. To understand it, we need to go back to the relationship between human rights and (democratic) politics and, accordingly, to the role of international human rights law and its complementary relation to domestic human rights law. The proposed argument is three-pronged. After a first section on subsidiarity in international human rights law and the different shapes it takes in practice, the second section compares human rights subsidiarity with the subsidiarity encountered in other social,
\end{abstract}

* Professor of Public International Law and European Union Law, University of Fribourg, Switzerland. Email: samantha.besson@unifr.ch. Many thanks to Nick Barber, Richard Ekins and Paul Yowell for their invitation to present a previous version of this article at their Constitutional Theory Seminar in Oxford on $7^{\text {th }}$ May, 2015; to Francis Cheneval for his invitation to discuss it at his Political Theory Colloquium in Zürich on 27th May, 2015; to Sébastien Touzé for his invitation to present a more applied version at the Conference on the Future of the European Court of Human Rights in Paris on 19 $9^{\text {th }}$ November, 2015; and to Katerina Linos and Sujit Choudhry for their invitation to discuss it at the Colloquium in International Law and Politics at Berkeley Law School on $2^{\text {nd }}$ February, 2016. Thanks to Maria Cahill, Leslie Green, Martin Beckstein, Jahel Queralt and Christopher Kutz for their helpful comments on these occasions. I am very grateful also to John Finnis for his extremely helpful editorial comments. Last but not least, I would like to thank Odile Ammann and Matthieu Loup respectively for their research assistance and help with the edition of the manuscript. 
political and legal contexts, and does so with respect to different dimensions of subsidiarity: its subjects, objects, functions, justifications, tests, limits and reviews. The third section draws various implications of the specificity of human rights subsidiarity, and in particular for how we should go about interpreting it and addressing some of the challenges it is currently facing in practice.

Keywords: Subsidiarity; complementarity; human rights; equality; democracy; margin of appreciation; supranational judicial review

\begin{abstract}
"It is also important to emphasise the fundamentally subsidiary role of the Convention mechanism. The national authorities have direct democratic legitimation and are, as the Court has held on many occasions, in principle better placed than an international court to evaluate local needs and conditions. In matters of general policy, on which opinions within a democratic society may reasonably differ widely, the role of the domestic policy-maker should be given special weight."
\end{abstract}

SAS v. France, ECHR 2014 (not published yet) (CE:ECHR:2014: 0701JUD004383511), par. 129 (emphasis added).

\title{
I. Introduction
}

Subsidiarity is en vogue in international human rights law (IHRL). Recently, one author, now a judge at the European Court of Human Rights (ECtHR), argued that the 1950 European Convention on Human Rights (ECHR) ${ }^{1}$ had entered the "age of subsidiarity." 2

From a largely implicit and mainly jurisprudential principle used in discrete guises by international human rights bodies and courts since the $1960 \mathrm{~s},{ }^{3}$ subsidiarity has become increasingly present and even central in international human rights reasoning. ${ }^{4}$ The principle is actually about to be entrenched into the text of international human rights treaties. Thus, when Protocol 15 to the ECHR enters into force, a new recital on subsidiarity ${ }^{5}$ will be added into the Preamble to the ECHR, thereby making the subsidiarity principle an integral part of the

1 This article focuses on the ECHR for this is the international human rights legal regime where subsidiarity has been discussed most, as I will explain. I will come back to the differences between it and the other, both judicialized and non-judicialized, regional and international regimes later in the argument.

2 Robert Spano, "Universality or Diversity of Human Rights? Strasbourg in the Age of Subsidiarity," Human Rights Law Review 14 (2014): 487-502.

3 Since 23 $3^{\text {rd }}$ July, 1968 for subsidiarity: Case "relating to certain aspects of the laws on the use of languages in education in Belgium" $v$. Belgium, ECHR (1967) Series A no 5 (CE:ECHR:1967:0209JUD000147462), par. 10. And since $7^{\text {th }}$ December, 1976 for the margin of appreciation: Handyside v. United Kingdom, ECHR (1976) Series A no 24 (CE:ECHR:1976:1207JUD000549372), par. 48 and 54.

${ }^{4}$ See e.g. in recent case-law, Von Hannover v. Germany (No 2), ECHR 2012-I 399 (CE:ECHR:2012:0207JUD004066008); Mennesson v. France, ECHR 2014 (not published yet) (CE:ECHR:2014:0626JUD006519211); SAS v. France, ECHR 2014 (not published yet) (CE:ECHR:2014:0701JUD004383511). See also Alastair Mowbray, "Subsidiarity and the European Convention on Human Rights," Human Rights Law Review 15 (2015): 313-41, at 337-9. 
Convention itself and a principle that constrains the ECtHR as much as ECHR States Parties. ${ }^{6}$ Most recently, and in line with the subsidiarity-based approach adopted in the reform process of the ECtHR that has been constantly deepened since the conferences of Interlaken in 2010, Brighton in 2012 and Izmir in 2013, the March 2015 Brussels Declaration of the Council of Europe's Committee of Ministers stressed once again how important subsidiarity has become for the future of the Convention system. ${ }^{7}$

At the same time, however, one cannot but wonder at how quickly subsidiarity has become the cure to all ills. It has been endorsed by all sides in the current reform process of the ECtHR, and in particular by the States most averse to the Court's interventions in their domestic affairs, like Russia, the United Kingdom or Switzerland, and the Court alike. Gradually, indeed, subsidiarity has also been turned into an instrument for the ECtHR to prevent ECHR violations through its fast developing preventive and remedial $\operatorname{control}^{8}$ and to exercize an abstract control over States' institutional and procedural framework of human rights protection. ' This has enabled it to invoke subsidiarity to prevent human rights' violations and hence to handle its docket. Judicial statistics actually confirm that the increasing references to subsidiarity in the ECtHR's case-law since 2010 do not result from States Parties' applications and pleadings, as one might expect, but from the Court itself, and especially from dissenting judges. ${ }^{10} \mathrm{~A}$ first explanation for this success may be the so-called "duality of subsidiarity" and, more exactly, its background: the primary responsibility of national authorities in the Convention system. ${ }^{11}$ When the "two sides" of the

5 "Affirming that the High Contracting Parties, in accordance with the principle of subsidiarity, have the primary responsibility to secure the rights and freedoms defined in this Convention and the Protocols thereto, and that in doing so they enjoy a margin of appreciation, subject to the supervisory jurisdiction of the European Court of Human Rights established by this Convention." (art. 1 Protocol 15 ECHR). See another reference to subsidiarity in par. 3 of the Preamble to Protocol 16 ECHR.

${ }^{6}$ See e.g. Frédéric Sudre, "La subsidiarité, 'nouvelle frontière' de la Cour européenne des droits de l'homme - A propos des Protocoles no 15 et 16 à la Convention," La Semaine Juridique Edition Générale 87 (2013): 1912-20; David Milner, "Protocols 15 and 16 to the European Convention on Human Rights in the Context of the Perennial Process of Reform: A Long and Winding Road," Zeitschrift für Europarechtliche Studien 17(2014): 19-51; Paul Tavernier, "La constitutionnalisation de la marge d'appréciation dans le droit de la Convention européenne des droits de l'homme (Protocole 15)," in A Future for the Margin of Appreciation (Oxford: Oxford University Press, forthcoming 2016).

7 See on these various declarations and the ECHR reform process, http://www.coe.int/t/DGHL/ STANDARDSETTING/CDDH/REFORMECHR/.

8 See e.g. Janneke Gerards, "Advisory Opinions, Preliminary Rulings and the New Protocol 16 to the European Convention on Human Rights-A Comparative and Critical Appraisal," Maastricht Journal of European and Comparative Law 4 (2014): 630-51.

9 See e.g., Edouard Dubout, "La procéduralisation des droits," in Le principe de subsidiarité au sens du droit de la Convention européenne des droits de l'homme, ed. Frédéric Sudre (Bruxelles: Nemesis, 2014), 264-300.

10 See Mowbray, "Subsidiarity and the European Convention on Human Rights."

11 See e.g., Helen Keller and Amrei Müller, "Das Zusammenspiel von Bundesgericht und EGMR analysiert aus dem Blickwinkel der Subsidiarität." Justice - Justiz-Giustizia 1 (2012): 2-24, drawing on Jonas Christoffersen, Fair Balance: Proportionality, Subsidiarity and Primarity in the European Convention on Human Rights (Leiden: Martinus Nijhoff, 2009); Spano, "Universality or Diversity of Human Rights? Strasbourg in the Age of Subsidiarity"; Jean-Marc Sauvé, "Subsidiarity: A Two-Sided 
"subsidiarity-coin"12 are placed in perspective, it is clear that subsidiarity is not a free rein to States' appreciation, but a reminder of the possibility of reversing the priority or "primarity" 13 of domestic human rights implementation when the protection of ECHR rights is not effective. ${ }^{14}$ It is easy therefore to see how such a reminder of "shared responsibilities" could please both States and the Court. ${ }^{15}$ Still, is it correct to speak of "responsibilities" of the ECtHR in this case and how could an international court "share" them on a par with the institutions of a State? May subsidiarity be invoked to determine human rights' duties before States get a chance to do so? So, it seems that human rights subsidiarity has come to mean different things to different actors: the "sanctuarization" of States Parties' interpretations of ECHR rights for some ${ }^{16}$ and the "constitutionalization" of the ECtHR's control for others. ${ }^{17}$

These recent developments in the legalization of subsidiarity in international human rights law (hereafter, "human rights subsidiarity") and the (renewed) conceptual uncertainty they have brought about make it important to enquire theoretically about it. ${ }^{18}$ Past the usual truisms about subsidiarity, and in particular the fact that, according to it, (i) States have the primary responsibility to secure human rights, on the one hand, and (ii) international human rights institutions have only a supervisory function (ii.i.) in cases where minimal human rights standards are not protected effectively (ii.ii.), on the other, the fact is that the structure, function and justification of subsidiarity in international human rights law remain very difficult to capture.

Coin? - The Role of the National Authorities." European Court of Human Rights. http://www.echr. coe.int/Documents/Speech_20150130_Seminar_JMSauv\%C3\%A9_ENG.pdf.

12 See "ECtHR Background paper, Subsidiarity: A Two-Sided Coin?," European Court of Human Rights. http://www.echr.coe.int/Documents/Seminar_background_paper_2015_ENG.pdf.

13 On "primarity" by contrast to "subsidiarity" see Christoffersen. Fair Balance: Proportionality, Subsidiarity and Primarity in the European Convention on Human Rights.

${ }_{14}$ See the 2012 Brighton Declaration, par. 3, http://www.echr.coe.int/Documents/2012 Brighton_FinalDeclaration_ENG.pdf. See also Dean Spielmann, "Whither the Margin of Appreciation?," Current Legal Problems 67 (2014): 49-65.

15 See e.g., Spano. "Universality or Diversity of Human Rights? Strasbourg in the Age of Subsidiarity,"; Spielmann, "Whither the Margin of Appreciation?"; Françoise Tulkens, "Conclusions generals," in Le principe de subsidiarité au sens du droit de la Convention européenne des droits de l'homme (Bruxelles: Nemesis, 2014), 397-408; Jenneke Gerards, Janneke, "The European Court of Human Rights and National Courts-Giving Shape to the Notion of "Shared Responsibility," in Implementation of the ECHR and of the Judgments of the ECtHR in National Case Law. A Comparative Analysis (Antwerp: Intersentia, 2014), 13-94.

16 See e.g., Frédéric Sudre, "Le recadrage de l'office du juge européen," in Le principe de subsidiarité au sens du droit de la Convention européenne des droits de l'homme (Bruxelles: Nemesis, 2014), 239-64.

17 See e.g., Fiona de Londras, “The European Court of Human Rights, Dual Functionality, and the Future of the Court after Interlaken," Irish Human Rights Law Review 2011.

18 See also Andreas Føllesdal, "Appreciating the Margin of Appreciation," in Human Rights: Moral or Political?, ed. Adam Etinson (Oxford: Oxford University Press, forthcoming 2016); George Letsas, "The Margin of Appreciation Revisited: A Response to Føllesdal," in ibid.; Dubout, "La procéduralisation des droits"; Jenneke Gerards, "Pluralism, Deference and the Margin of Appreciation Doctrine," European Law Journal 17 (2011): 80-120; Jan Kratochvíl, "The Inflation of the Margin of Appreciation by the European Court of Human Rights," Netherlands Quarterly of Human Rights 29 (2011): 324-57; George Letsas, "Two Concepts of the Margin of Appreciation," Oxford Journal of Legal Studies 26 (2006): 705-32, reprinted in Letsas, A Theory of Interpretation of the European Convention on Human Rights (Oxford: Oxford University Press, 2007). 
Broadly speaking, scholarly strategies have divided into two groups. Most authors to date have focused on one aspect of subsidiarity ${ }^{19}$ (mostly the margin of appreciation of domestic authorities), while fewer have looked at the broader underpinning principle ${ }^{20}$-sometimes, even more rarely, they have even done

19 See e.g., on the margin of appreciation: Føllesdal, "Appreciating the Margin of Appreciation"; Letsas, "The Margin of Appreciation Revisited"; Kanstantsin Dzhetsiarou, European Consensus and the Legitimacy of the European Court of Human Rights (Cambridge: Cambridge University Press, 2015); Mads Andenas, Eirik. Bjorge, and Giuseppe Bianco, eds., A Future for the Margin of Appreciation (Oxford: Oxford University Press, forthcoming 2016); Tavernier, "La constitutionnalisation de la marge d'appréciation"; Spielmann, "Whither the Margin of Appreciation?"; Luzius Wildhaber, Arnaldur Hjartarson, and Stephen Donnelly, "No Consensus on Consensus? The Practice of the European Court of Human Rights," Human Rights Law Journal 33 (2013): 24863; Andrew Legg, The Margin of Appreciation in International Human Rights Law-Deference and Proportionality (Oxford: Oxford University Press, 2012); Kratochvill, "The Inflation of the Margin of Appreciation"; Gerards, "Pluralism, Deference and the Margin of Appreciation Doctrine"; Konstantsin Dzehtsiarou, "Does Consensus Matter? Legitimacy of European Consensus in the Case Law of the European Court of Human Rights," Public Law (2011): 534-53; Dean Spielmann, "Allowing the Right Margin: The European Court of Human Rights and the National Margin of Appreciation Doctrine: Waiver or Subsidiarity of European Review?," Cambridge Yearbook of European Legal Studies 14 (2011): 381-418; Yutaka Arai-Takahashi, The Margin of Appreciation Doctrine and the Principle of Proportionality in the Jurisprudence of the ECHR (Oxford and New York: Intersentia, 2001); Letsas, "Two Concepts of the Margin of Appreciation"; Jeffrey A. Brauch, "The Margin of Appreciation and the Jurisprudence of the European Court of Human Rights: Threat to the Rule of Law," Columbia Journal of European Law 11 (2004): 113-50; Steven Greer, The Margin of Appreciation: Interpretation and Discretion under the European Convention on Human Rights - Human Rights Files $n^{\circ} 17$ (Strasbourg: Council of Europe Publishing, 2000); Johan Callewaert, "Quel avenir pour la marge d'appréciation?," in Protection des droits de l'homme: la perspective européenne, Mélanges à la mémoire de Rolv Ryssdal 1 Protecting Human Rights: The European Perspective, Studies in Memory of Rolv Ryssdal, ed. Paul Mahoney et al. (Cologne et al.: Carl Heymanns Verlag, 2000), 147-66; Eva Brems, "The Margin of Appreciation Doctrine in the Case-Law of the European Court of Human Rights," Zeitschrift für ausländisches öffentliches Recht und Völkerrecht 56 (1996): 240-314; Howard C. Yourow, The Margin of Appreciation Doctrine in the Dynamics of the European Court of Human Rights Jurisprudence (London, New York, The Hague: Martinus Nijhoff and Kluwer Press, 1996); Rolv Ryssdal, "The Coming of Age of the European Convention of Human Rights," European Human Rights Law Review 1 (1996): 18-29. Ronald St. J. MacDonald, "The Margin of Appreciation," in The European System for the Protection of Human Rights, ed. Ronald St.J. MacDonald et al. (Dordrecht et al.: Martinus Nijhoff, 1993), 83-124. See e.g., on remedial subsidiarity: Abdelgawad E. Lambert, The Execution of Judgments of the European Court of Human Rights, $2^{\mathrm{d}} \mathrm{ed}$. (Strasbourg: Council of Europe Publishing, 2008); X.-B. Ruedin, L'exécution des arrêts de la Cour Européenne des Droits de l'Homme: procédure, obligations des Etats, pratique et réforme (Bruxelles: Bruylant, 2009).

20 Interestingly, while the first mention of subsidiarity in the ECtHR's case-law dates back to 1968, its first academic discussions only occurred in the early 1990s. See e.g., Federico Fabbrini, "The Margin of Appreciation and the Principle of Subsidiarity: A Comparison," in A Future for the Margin of Appreciation, ed. Mads Andenas, Eirik Bjorge, Giuseppe Bianco (Oxford: Oxford University Press, forthcoming): http://papers.ssrn.com/sol3/papers.cfm?abstract_id=2552542; Sabino Cassese, "Subsidiarity: A Two-Sided Coin?-Ruling Indirectly-Judicial Subsidiarity in the ECHR," European Court of Human Rights. http://www.echr.coe.int/Documents/Speech_20150130_ Seminar_Cassese_ENG.pdf; Sauvé, "The Role of National Authorities"; Spano, "Universality or Diversity of Human Rights? Strasbourg in the Age of Subsidiarity"; Sudre, "Le recadrage de l'office du juge européen"; Laurence Burgorgue-Larsen, "Subsidiarité et juges suprêmes nationaux, du contrôle de constitutionnalité à la collaboration juridictionnelle. Approche de droit compare," in Le principe de subsidiarité au sens du droit de la Convention européenne des droits de l'homme, ed. Frédéric Sudre (Bruxelles: Nemesis, 2014), 301-30; David Szymczak, 2014. "Rapport introductif: le principe de subsidiarité dans tous ses états," in ibid., 15-40; Gerald L. Neuman, "Subsidiarity," in Oxford Handbook of International Human Rights Law (Oxford: Oxford University Press, 2013), 36078; Sudre. "La subsidiarité, 'nouvelle frontière' de la Cour européenne des droits de l'homme"; Keller 
both $^{21}$. The former usually neglect the broader question, ${ }^{22}$ however, while the latter are often too quickly impressed by certain dimensions of the prestigious history of the principle of subsidiarity ${ }^{23}$ and rapidly identify human rights subsidiarity with other conceptions of subsidiarity that prevail in other legal and political contexts (e.g., in a federal polity ${ }^{24}$, in the European Union $[E U]^{25}$ or in Catholic social doctrine $\left.{ }^{26}\right)$.

and Müller, "Das Zusammenspiel von Bundesgericht und EGMR"; Jean-Marc Sauvé, "Le principe de subsidiarité et la protection européenne des droits de l'homme," Recueil Dalloz no. 22 (10 Juin 2010), 1368-1373; William M. Carter, Jr., "Rethinking Subsidiarity in International Human Rights Adjudication," Hamline Journal of Public Law and Policy 30 (2008): 319-34; Christoffersen, "Fair Balance: Proportionality, Subsidiarity and Primarity in the European Convention on Human Rights"; Laurence R. Helfer, "Redesigning the European Court of Human Rights: Embeddedness as a Deep Structural Principle of the European Human Rights Regime," European Journal of International Law 19 (2008): 125-59; Stephan Breitenmoser, "Subsidiarität und Interessenabwägung im Rahmen der EGMR-Rechtsprechung," in Human Rights, Democracy and the Rule of Law / Menschenrechte, Demokratie und Rechtsstaat / Droits de l'homme, démocratie et Etat de droit - Liber Amicorum Luzius Wildhaber (Zurich: Dike, 2007), 119-41; Mark Villiger, "The Principle of Subsidiarity in the European Convention on Human Rights," in Promoting Justice, Human Rights and Conflict Resolution through International Law / La promotion de la justice, des droits de l'homme et du règlement des conflits par le droit international - Liber Amicorum Lucius Caflisch (Leiden: Martinus Nijhoff, 2007), 623-37; Irene Hoffmann, Der Grundsatz der Subsidiarität im Rechtsschutzsystem der Europäischen Menschenrechtskonvention - Rechtliche Fundierung, Besonderheiten und Bedeutung (Frankfurt am Main: Lang, 2007); Dinah Shelton, "Subsidiarity and Human Rights Law," Human Rights Law Journal 27 (2006): 4-11; Paolo G. Carozza, "Subsidiarity as a Structural Principle of International Human Rights Law," American Journal of International Law 97 (2003): 38-79; Michele de Salvia, "Contrôle européen et principe de subsidiarité - Faut-il encore (et toujours) émerger à la marge d'appréciation?," in Mahoney et al., ed., Protection des droits de l'homme: la perspective européenne, 373-85. Paul Mahoney, "Universality versus Subsidiarity in the Strasbourg Case Law on Free Speech: Explaining Some Recent Judgments," European Human Rights Law Review 4 (1997): 364-79; Herbert Petzold, "The Convention and the Principle of Subsidiarity," in MacDonald et al., eds., The European System for the Protection of Human Rights, 41-62.

${ }_{21}$ See e.g., Mowbray, "Subsidiarity and the European Convention on Human Rights."

22 See even Letsas, "Two Concepts of the Margin of Appreciation"; Føllesdal "Appreciating the Margin of Appreciation"; Letsas "The Margin of Appreciation Revisited."

${ }^{23}$ For discussions of the principle in various contexts, see e.g., Michelle Evans and Augusto Zimmermann, eds. Global Perspectives on Subsidiarity (Dordrecht: Springer, 2014); Andreas Føllesdal, "The Principle of Subsidiarity as a Constitutional Principle in International Law," Global Constitutionalism 2 (2013): 37-62; Isabel Feichtner, "Subsidiarity," in Max Planck Eynclopedia of International Law, Vol IX (Oxford: Oxford University Press, 2007), 652-58; N.W. Barber, "The Limited Modesty of Subsidiarity," European Law Journal 11 (2005): 308-25; Andreas Føllesdal, "Subsidiarity and Democratic Deliberation," in Democracy and the European Union: Integration through Deliberation, ed. Erik Odvar Eriksen and John Erik Fossum (London: Routledge, 1999), 85-110; Andreas Føllesdal, "Survey Article: Subsidiarity," Journal of Political Philosophy 6 (1998): 190-218.

${ }^{24}$ See e.g., Fabbrini, "The Margin of Appreciation and the Principle of Subsidiarity: A Comparison"; Cassese, "Ruling Indirectly_-Judicial Subsidiarity in the ECHR."

${ }^{25}$ See e.g., Mowbray. "Subsidiarity and the European Convention on Human Rights"; Fabbrini, "The Margin of Appreciation and the Principle of Subsidiarity: A Comparison." For a more nuanced position, F.J. Mena Parras, "From Strasbourg to Luxembourg? Transposing the Margin of Appreciation Concept into EU Law," Centre Perelman de philosophie du droit, Working Paper $7 /$ 2015. http://www.philodroit.be/IMG/pdf/fm_transposing_the_margin_of_appreciation_concept_ into_eu_law_-_2015-7.pdf.

${ }^{26}$ See e.g., Shelton, "Subsidiarity and Human Rights Law"; Carozza, "Subsidiarity as a Structural Principle of International Human Rights Law." For a historical explanation of the connection, see Julien Barroche, "Subsidiarite," in DicoPo, Dictionnaire de théorie politique (2007) 
In this article, I would like to argue that the concept of subsidiarity is at play in international human rights law, but that the structure, function and justification of human rights subsidiarity are very different from those of the other conceptions of subsidiarity we know of in other contexts. To grasp it, we need to go back to the relationship between human rights and (democratic) domestic politics and, accordingly, to the role of international human rights law and its complementary relation to domestic human rights law. The proposed argument is three-pronged. After a first section on subsidiarity in international human rights law where I identify the different shapes it takes in practice (I.), the second section compares human rights subsidiarity so identified with the conceptions of subsidiarity encountered in other political and legal contexts, and does so with respect to the different dimensions of subsidiarity: its subjects, objects, functions, tests, justifications, limits and review (II.). The third section draws various implications of the specificity of human rights subsidiarity for how we should go about interpreting some of its dimensions in practice (III.).

A final methodological caveat is in order. The article is part of a more general project of developing a legal theory of human rights. ${ }^{27}$ Starting from legal questions and categories, it proposes an interpretation of international human rights law. Concretely, in this case, starting from the practice of subsidiarity in international human rights law, however multidimensional and contradictory it may seem at first sight, ${ }^{28}$ the article seeks to identify the principle of subsidiarity at play and to interpret it comparatively and critically in a way that fits and justifies that normative practice. This means identifying both the justifications and critiques underpinning the practice of subsidiarity in international human rights law, in order to present the existing law and practice in its best light. Like any legal interpretation, the proposed interpretation of human rights subsidiarity is constrained and shaped by the normative practice of law, but it is also part of that practice and hence constrains and shapes it in return. So-doing, the theory of human rights subsidiarity I propose is not trapped in the kind of normatively inert descriptions of human rights practice one finds in some so-called "political" theories of human rights, ${ }^{29}$ on the one hand, but it is not freed from that practice and from having to account for it as are the kind of practice-guiding normative accounts of moral human rights one finds in some so-called "ethical" human rights theories, ${ }^{30}$ on the other.

http://www.dicopo.fr/spip.php?article61; Julien Barroche, Etat, libéralisme et christianisme—Critique de la subsidiarité européenne (Paris: Dalloz, 2012).

27 See e.g., Samantha Besson, "The Law in Human Rights Theory," Journal for Human Rights 7 (2013): 120-50; Samantha Besson, "Legal Human Rights Theory," in Blackwell Companion to Applied Philosophy, ed. David Cody, Kimberley Brownlee, and Kasper Lipper-Rasmussen (London: Blackwell Wiley, forthcoming 2016).

28 See also Nicholas W. Barber, "The Significance of the Common Understanding in Legal Theory," Oxford Journal of Legal Studies 35 (2015): 799-823.

29 See e.g., Charles Beitz, The Idea of Human Rights (Oxford, Oxford University Press, 2009).

30 See e.g., James Griffin, On Human Rights (Oxford, Oxford University Press, 2008). 


\section{Human Rights Subsidiarity in Practice}

This first section captures the practice of subsidiarity in international human rights law and practice in order to prepare for its comparison, in the second section, with the conceptions of subsidiarity at play in other legal and political contexts. It does so, first of all, by identifying the context of human rights subsidiarity and especially that of the complementary relationship between domestic and international human rights law (A.); secondly, by identifying three types of human rights subsidiarity in international human rights law (B.); and, finally, by delineating human rights subsidiarity so identified from other related features of international human rights law (C.).

\section{A. Human Rights Subsidiarity in Context}

Domestic international human rights law and international human rights law relate in many ways that cannot be adequately captured solely by reference to the principle of subsidiarity. It is important therefore to identify those relations as the broader context for human rights subsidiarity, in order then to focus on subsidiarity itself.

In the post- 1945 contemporary human rights practice, human rights are protected both by domestic and international law. This dual human rights regime has been famously described by Gerald Neuman as the "dual positivization" of human rights. ${ }^{31}$ Constitutional and international human rights lawyers alike have long been puzzled by the co-existence of these two legal regimes of human rights and wondered about their relationship.

Clearly, the reason for this dual human rights regime does not lie in legal history or genealogy as both types of legal human rights norms date back roughly to the same post-1945 era. The so-called international "bill of rights," i.e., the Universal Declaration of Human Rights (UDHR), the International Covenant on Civil and Political Rights (ICCPR) and the International Covenant on Economic, Social and Cultural Rights (ICESCR), was drafted on the basis of existing domestic bills of rights and at the same time, or shortly hereafter, most existing domestic bills of rights or constitutions were either completely revised or drafted anew on the basis of these international human rights treaties. This confirms the synchronic nature of their functions and even a co-existence requirement. ${ }^{32}$ Nor does the reason for their co-existence lie in the content or the structure of the human rights protected, as those are held to be, by and large, similar in practice and should be so. ${ }^{33}$ International human rights law is not there to fill the gaps of domestic law, in other words. Nor, finally, does the key to the relationship between domestic and international human rights lie in their enforcement mechanisms. Both human rights regimes should indeed be implemented and monitored by domestic

31 Gerald L. Neuman, "Human Rights and Constitutional Rights," Stanford Law Review 55 (2003): 1864.

32 See also Stephen Gardbaum, "Human Rights as International Constitutional Rights," European Journal of International Law 19 (2008): $764 \mathrm{ff}$.

33 Gardbaum, "Human Rights as International Constitutional Rights," 750-51. 
institutions, before the potential supervision by the international machinery of collective enforcement established by IHRL. ${ }^{34}$

So, what could explain that the two regimes are not merely juxtaposed, and hence concurrent or redundant at best? They have, I have argued elsewhere, distinct albeit complementary functions that make them dependent on one another. $^{35}$ The complementarity of the functions of domestic and international human rights law actually explains how they arise together and cannot be separated in their law-making process and sources. These features correspond to what I have referred to elsewhere as the mutual validation and legitimation of domestic and international human rights law. ${ }^{36}$ International human rights stem from the transnational consolidation of domestic human rights in democratic States and constrain the latter in return.

In a nutshell, the international or externalized human rights law regime has three functions that make it complementary to domestic human rights law: ${ }^{37}$ (i) a substantive one: it requires the protection of the minimal and abstract content of those rights against domestic levelling-down; ${ }^{38}$ (ii) a personal one: it requires the minimal inclusion of all those subjected to domestic jurisdiction, territorially and extra-territorially and whether they are nationals or not, in the personal scope of those rights; ${ }^{39}$ and (iii) a procedural one: it requires the introduction of minimal internal institutional, and especially judicial, mechanisms of implementation of those rights and monitoring/review thereof that are complemented by some form, whether judicial or political, of international and hence external human rights monitoring. ${ }^{40}$

It is the third relationship of complementarity between domestic and international institutional mechanisms of monitoring or review that is captured by the idea and principle of ("procedural") subsidiarity in practice. Of course, traces of the other two dimensions of complementarity between international and human rights law are also to be found in the ways in which human rights subsidiarity applies, and especially in what I will refer to as "substantive" subsidiarity. Note, however, that human rights subsidiarity is always institutional, and hence procedural, to the extent that all types of subsidiarity qualify the reviewing competence of international human rights institutions and courts, even if this then takes different shapes depending on whether it pertains to their power to review

\footnotetext{
34 See Samantha Besson, "Human Rights and Constitutional Law: Mutual Validation and Legitimation," in Philosophical Foundations of Human Rights, ed. Rowan Cruft, S. Matthew Liao, and Massimo Renzo (Oxford: Oxford University Press, 2015), 279-99. See also Ronald Dworkin, Justice for Hedgehogs (Cambridge, MA: Harvard University Press, 2011), 333-4; Kristen Hessler, "Resolving Interpretive Conflicts in International Human Rights Law," Journal of Political Philosophy 13 (2005): 37.

35 See Besson, "Human Rights and Constitutional Law." See also Dworkin, Justice for Hedgehogs, $334-5$.

36 See Besson, "Human Rights and Constitutional Law"; Samantha Besson, "The Sources of International Human Rights Law," in Oxford Handbook on the Sources of International Law (Oxford: Oxford University Press, forthcoming 2017).

37 See Besson, "Human Rights and Constitutional Law."

38 See Gardbaum, "Human Rights as International Constitutional Rights," 764.

39 Ibid., 765-6, 767.

40 See also Dworkin, Justice for Hedgehogs, 334-5.
} 
("procedural subsidiarity"), to the latter's intensity ("substantive subsidiarity") or to its scope ("remedial subsidiarity").

\section{B. Three Types of Human Rights Subsidiarity}

A descriptive survey of international human rights law and practice shows that human rights subsidiarity is usually approached as a two-sided principle: States have the primary responsibility to secure human rights under their jurisdiction, and international human rights institutions have a complementary review power in cases where international minimal human rights standards are not protected effectively domestically. ${ }^{41}$ More specifically, the survey reveals three types of human rights subsidiarity: "procedural," when it pertains to the actual power or competence of the international human rights court or body to review (i.); "substantive," when it qualifies the intensity of that review (ii.); and "remedial," when it pertains to the scope of the review (iii.).

Because the application of the principle of subsidiarity in international human rights law has developed through practice and especially judicial practice and has not (yet) been entrenched in the text of international human rights instruments, those three types of subsidiarity and their distinct labels are mostly doctrinal reconstructions of that practice. ${ }^{42}$ They have, however, been recently vindicated by judicial practice itself. ${ }^{43}$ Further, independently from the exact categories and labels, they are all regarded as derivations of the same principle of subsidiarity by international human rights courts or bodies in practice. ${ }^{44}$ I will come back to the central question of the conceptual unity of subsidiarity and of the comparative conceptual belonging of human rights subsidiarity in the next section.

Interestingly, it is within international human rights law regimes that are judicialized, like the ECHR or the 1969 American Convention of Human Rights (with its Court, the Inter-American Court of Human Rights [IACtHR]), that one encounters all three types of human rights subsidiarity. ${ }^{45}$ In other international human rights regimes, the general rule seems to be that the less institutionalized

${ }^{41}$ See e.g., "ECtHR Background paper, Subsidiarity: A Two-Sided Coin?," 1.

42 See e.g., Samantha Besson, "Human Rights Adjudication as Transnational AdjudicationPutting Domestic Courts as International Law Adjudicators in Perspective. In International Law and ..., ESIL Proceedings of the 10 $0^{\text {th }}$ Anniversary Conference (Oxford: Oxford University Press, forthcoming 2016); Samanth Besson, "The 'Erga Omnes' Effect of Judgments of the European Court of Human Rights-What's in a Name?," in La Cour européenne des droits de l'homme après le Protocole 14: premier bilan et perspectives (Zurich: Schulthess, 2011), 125-75.

43 See e.g., "ECtHR Background paper, Subsidiarity: A Two-Sided Coin?," 3-7.

44 See e.g., "ECtHR Background paper, Subsidiarity: A Two-Sided Coin?," 3-7.

45 The other international human rights courts or bodies considered are the IACtHR (another regional international human rights court) and the Human Rights Committee (HRC) and the Committee on the Elimination of Racial Discrimination (CERD) (two UN human rights treaty bodies). The former is a regional international human rights court like the ECtHR albeit in another region. The HRC is the international human rights treaty body that comes closest to the ECtHR in terms of the rights protected, and the CERD is the eldest UN human rights treaty body. Note that this article's argument does not draw a distinction between regional and universal international human rights' instruments: they are all international in nature and, as a result, equally complementary to domestic (democratic) human rights law. It would be wrong therefore to conceive of the relations between regional and universal international human rights bodies' or courts' review as being based on subsidiarity. On these relations and the transnational consolidation of international human 
they are, the less subsidiarity is invoked and respected. Thus, while some forms of subsidiarity may be identified in the practice of UN human rights treaty bodies, very few subsidiarity requirements subsist in individual procedures before the Human Rights Council. A second observation is that, even before human rights treaty bodies, if procedural subsidiarity is usually respected, it is not the case with substantive subsidiarity or only in a very limited fashion, ${ }^{46}$ and clearly not the case with remedial subsidiarity. This may be explained by reference to the lack of legally binding force of these bodies' views and observations, but also, $a$ contrario, by reference to the specificities and importance of judicial reasoning in the human rights context.

\section{i. Procedural Subsidiarity}

Procedural subsidiarity pertains to the power or competence to review of an international human rights court or body. It derives from and confirms, at least negatively, the primary procedural, and especially judicial, responsibility of States in the monitoring and reviewing of the implementation of international human rights law (e.g., arts. 1, 13, 19 and 52 ECHR ${ }^{47}$. More specifically, procedural subsidiarity founds the two following requirements, or "rules," 48 for an international human rights body or court to be able to exercize its complementary review: first of all, the exhaustion of (effective) domestic remedies (e.g., art. 35(1) ECHR) and, secondly, respect for the further admissibility conditions for an application before the ECtHR (e.g., art. 1, 34 and 35 ECHR). ${ }^{49}$

Under the ECHR system, the first requirement of procedural subsidiarity is the obligation to exhaust domestic remedies under art. 35(1) ECHR. The Court stated in Vučkovic and Others $v$. Serbia that "the rule of exhaustion of domestic remedies is based on the assumption-reflected in Article 13 of the Convention, with which it has close affinity - that there is an effective [domestic] remedy available in respect of the alleged violation. The rule is therefore an indispensable part of the functioning of this system of protection." ${ }^{50}$ Art. 35(1) ECHR requires that the complaints brought to the ECtHR should have first been made to the appropriate domestic body and, further, that any procedural means that might prevent a breach of the Convention should have been exhausted. Applicants are not, however, required to invoke the Convention right relied on expressly in the domestic proceedings. It is enough that they have raised the issue in substance or implicitly. ${ }^{51}$ Moreover, only those domestic remedies deemed "effective" have to

rights law, more generally, see Samantha Besson, "Human Rights as Transnational Constitutional Law," in Handbook on Global Constitutionalism (London: Elgar, forthcoming 2017).

46 See e.g., HRC, General Comment No. 34 (CCPR/C/GC/34, 2011), par. 36.

47 See e.g., Kudla v. Poland, ECHR 2000-XI 197 (CE:ECHR:2000:1026JUD003021096), par. 152; Austin and Others v. United Kingdom, ECHR 2012-II 423 (CE:ECHR:2012: 0315JUD003969209), par. 61. See also Keller and Müller, "Das Zusammenspiel von Bundesgericht und EGMR."

48 See e.g., Vučković and Others v. Serbia (preliminary objection), App no 17153/11 et. al. (ECtHR, 25 March 2014, CE:ECHR:2014:0325JUD001715311), par. 69.

49 See e.g., "ECtHR Background paper, Subsidiarity: A Two-Sided Coin?," 3-4.

50 Vučkovic and Others v. Serbia, par. 69.

51 Azinas v. Cyprus, ECHR 2004-III (CE:ECHR:0428JUD005667900), par. 38. 
be exhausted and the Court has interpreted this autonomous notion very broadly. ${ }^{52}$

A second set of requirements of procedural subsidiarity may be found in the other admissibility rules under arts. 1, 34 and 35 ECHR. One may mention two in particular: the six-month time-limit for an individual application, that will be reduced to four months once Protocol 15 is in force (art. 4), and the prohibition of actio popularis through the requirement that the applicant should be a "concrete and individual victim" (art. 34 ECHR) of the alleged violation of human rights. The former aspect ensures that review by the ECtHR can occur sufficiently close in time to the actual violation of the Convention. The latter ensures that its review is concrete and does not involve or lead to the abstract judicial review of domestic legislation, because this is a competence that remains solely in the domestic sphere.

\section{ii. Substantive Subsidiarity}

Substantive subsidiarity qualifies the intensity and content of the review the international human rights court or body may exercise once the conditions imposed by procedural subsidiarity are fulfilled and it is allowed to exercise its review power. It includes two so-called jurisprudential "doctrines" or "rules" 33 (as they have been developed e.g., by the ECtHR): first, the fourth-instance doctrine and, second, the margin of appreciation of domestic authorities. Substantive subsidiarity is also understood as underpinning a third rule: the principle of favor.

First of all, under the fourth-instance doctrine, the ECtHR considers that it has only limited power to review that facts have been assessed correctly and that domestic law has been well interpreted and applied. It is not its role to take the place of national courts, thereby becoming a kind of fourth instance, ${ }^{54}$ but only to ensure that the decisions of these courts are not flawed by arbitrariness or otherwise manifestly unreasonable. ${ }^{55}$ It is only when the assessment of facts and law by domestic courts may itself amount to a breach of the ECHR that the Court's review will extend into these areas. It remains unclear, however, from the ECtHR's case-law when this should be the case, on the one hand, and what the arbitrariness control should amount to exactly, on the other. ${ }^{56}$ The fourth instance doctrine operates mostly in a judicial context. ${ }^{57}$

Secondly, the margin of appreciation doctrine is the most prominent jurisprudential derivation from substantive subsidiarity. ${ }^{58}$ The connection between the

\footnotetext{
52 Akdivar v. Turkey, ECHR 1996-IV (CE:ECHR:1996:0916JUD002189393), par. 69. See also Tulkens, "Conclusions générales."

53 See e.g., "ECtHR Background paper, Subsidiarity: A Two-Sided Coin?," 5-7.

${ }^{54}$ See e.g., Eckle v. Germany, ECHR (1982) Series A no 51 (CE:ECHR:1982:0715 JUD000813078), par. 66.

55 Anheuser-Busch Inc. v. Portugal, ECHR 2007-I 39 (CE:ECHR:2007:0111JUD007304901), par. 83.

56 See e.g. Dembelé v. Switzerland, App no 74010/11 (ECtHR, 24 September 2013, CE:ECHR:2013:0924JUD007401011). See also Judge Keller's dissenting opinion, par. 18-23.

57 Austin and Others v. United Kingdom, par. 61.

58 See Letsas, "Two Concepts of the Margin of Appreciation"; Letsas, "The Margin of Appreciation Revisited."
} 
two was first made by the ECtHR in the Handyside v. United Kingdom case ${ }^{59}$, and has now been confirmed by art. 1 Protocol 15.60 The margin of appreciation doctrine recognizes that there may be a range of different but justified interpretations of international human rights law depending on the domestic context. As a result, the Court should defer to the judgment of domestic authorities that are better placed to decide on what these are. That deference or self-restraint is not absolute, of course, or else the review and supervision power of the Court would be pointless.

The degree of stringency of the Court's review should vary depending on the degree of the margin of appreciation which national authorities enjoy. Regrettably, however, the scope, width and limits of States' margin of appreciation still remain unclear in the ECtHR's case-law. ${ }^{61}$ The Court also refers interchangeably to the "cases," "scope" or "factors" affecting the margin of appreciation. $^{62}$

In terms of scope, the margin of appreciation mostly-but not exclusivelyapplies to restrictions to human rights and, as a result, especially to human rights balancing. One can also find cases where the margin of appreciation is mentioned in relation to the determination of the scope and content of human rights. Importantly, the margin of appreciation does not only protect domestic judicial review. It also acknowledges the weight to be attached to the democratic process and the range of options that may be available to the domestic legislature when complying with the Convention. ${ }^{63}$ There seems to be a limit in the case-law, however: the margin of appreciation only applies provided domestic (judicial, legislative or executive) authorities can prove they have reasoned about the ECHR rights at stake and have offered reasons for their position. ${ }^{64}$

In terms of width or degree, the margin of appreciation is broad in two types of cases: first of all, cases where there is no "European consensus" and hence no common or converging approach among States Parties ${ }^{65}$ and, secondly, cases that pertain to morally or politically sensitive rights. ${ }^{66}$ The first group of cases include cases pertaining to issues about which there is persistent and widespread reasonable disagreement among and within European States and hence no consensus

\footnotetext{
59 Handyside v. United Kingdom, par. 48-50.

60 See e.g., Spielmann, "Whither the Margin of Appreciation?”; Spano, "Universality or Diversity of Human Rights? Strasbourg in the Age of Subsidiarity."

${ }^{61}$ See e.g., Dubout, "La procéduralisation des droits"; Gerards, "Pluralism, Deference and the Margin of Appreciation Doctrine"; Kratochvíl, "The Inflation of the Margin of Appreciation"; Letsas, "Two Concepts of the Margin of Appreciation."

${ }^{62}$ See e.g., "ECtHR Background paper, Subsidiarity: A Two-Sided Coin?," 5-7. See also S. and Marper v. United Kingdom, ECHR 2008-V 213 (CE:ECHR:2008:1204JUD003056204), par. 102.

63 Animal Defenders International v. United Kingdom, ECHR 2013-II 203 (CE:ECHR:2013:0422JUD004887608), par. 115-116. See Matthew Saul, "The European Court of Human Rights' Margin of Appreciation and the Processes of National Parliaments," Human Rights Law Review 15 (2015): 745-74.

${ }^{64}$ See e.g., Schalk and Kopf v. Austria, ECHR 2010-IV 409 (CE:ECHR:2010:0624 JUD003014104), dissenting opinion of Judges Rozakis, Spielmann and Jebens; $A$ v. Norway, App no 28070/06 (ECtHR, 9 April 2009, CE:ECHR:2009:0409JUD002807006), par. 74. See also Spano, "Universality or Diversity of Human Rights? Strasbourg in the Age of Subsidiarity," 12.

65 See Wildhaber, Hjartarson, and Donnelly, "No Consensus on Consensus?"

66 See Føllesdal, "Appreciating the Margin of Appreciation."
} 
about a minimal European standard yet. ${ }^{67}$ This applies in particular, but not only, to personal sphere rights (arts. 8-11 ECHR). The second group of cases includes cases that pertain to art. 15 ECHR derogations, ${ }^{68}$ but also by extension to the general positive duty of democratic States to organize themselves so as to protect human rights. This includes political and democratic rights in particular. There are variations, however, depending on the area: there is usually a lesser margin of appreciation with respect to restrictions to political speech than to commercial speech, given how important the former is in a democracy by comparison to the latter. ${ }^{69}$ It is interesting to note from these two factors influencing the width of the margin of appreciation in practice that the existence of European consensus does not necessarily preclude the recognition of a broad margin of appreciation of States, and vice-versa.

Finally, in terms of limits, there are some rights in relation to which the margin of appreciation has been excluded by the ECtHR. This is the case with violations of absolute ECHR rights (e.g., art. 3 ECHR), ${ }^{70}$ in particular, but also with the fundamental core of ECHR rights. Another case of exclusion or serious limitation of the margin of appreciation has been violation of non-discrimination rights (art. 14 ECHR). ${ }^{71}$

Thirdly, the principle of favor (e.g., art. 53 ECHR) captures the idea that international human rights standards are minimal and not maximal standards. According to that principle, ECHR rights should not be interpreted as preventing domestic authorities from setting and implementing higher standards of protection than those of ECtHR's case-law. The ECtHR's substantive review should therefore focus mostly on the enforcement of that minimal level of protection. The principle has not been invoked much in practice, however, nor interpreted in detail by the ECtHR, as a result. ${ }^{72}$

\section{iii. Remedial Subsidiarity}

Remedial subsidiarity protects the States' choice of remedial means after an adverse judgment of an international human rights body or court. Remedial subsidiarity is an extension of procedural and substantive subsidiarity ${ }^{73}$ to the extent

67 See e.g., Sitaropoulos and Giakoumopoulos v. Greece, ECHR 2012-II 279 (CE:ECHR:2012:0315JUD004220207).

68 See e.g., $A$ and Others v. United Kingdom, ECHR 2009-II 137 (CE:ECHR:2009:0219 JUD000345505), par. 174.

${ }^{69}$ Contrast e.g., Goodwin v. United Kingdom, ECHR 1996-II (CE:ECHR:1996:0327JUD 001748890) or Perinçek v. Switzerland, ECHR 2015 (not published yet) (CE:ECHR:2015: 1015JUD002751008) with Mouvement raëlien suisse v. Switzerland, ECHR 2012-IV 373 (CE:ECHR:2012:0713JUD001635406), par. 61.

70 See e.g., Saadi v. Italy, ECHR 2008-II 145 (CE: ECHR:2008:0229JUD003720106).

${ }^{71}$ See e.g., Fabris v. France, ECHR 2013-I 425 (CE:ECHR:2013:0207JUD001657408), par. 72.

72 See e.g., Catherine van de Heyning, "No Place like Home: Discretionary Space for the Domestic Protection of Fundamental Rights," in Human Rights Protection in the European Legal Order: Interaction between European Courts and the National Courts, ed. Patricia Popelier, Catherine van de Heyning, and Piet Van Nuffel (Cambridge: Intersentia, 2011), 65-96.

73 See e.g., "ECtHR Background paper, Implementation of the judgments of the European Court of Human Rights: a shared judicial responsibility?," European Court of Human Rights. http://www. echr.coe.int/Documents/Seminar_background_paper_2014_ENG.pdf. 
that a condemnation by an international human rights body or court gives rise to new human rights duties that have to be specified and implemented in priority by domestic authorities given their primary responsibility and discretion in the implementation of human rights in the first place.

In the ECHR system, remedial subsidiarity is based on art. 46(1) ECHR and the ECtHR's interpretation of the principle of restitutio in integrum. According to it, adverse judgments of the Court are declaratory (albeit being binding, of course) and do not identify or specify remedies for the violation identified. Adverse judgments of the Court therefore call for some form of domestic remedial enforcement that has to be determined by States themselves. As a result, States Parties have the responsibility to identify the best means to comply with the secondary duties stemming from the recognition of their international responsibilities (art. 19/46(1)/52 ECHR). That responsibility gives rise to duties to cease the violation, prevent further violations and remedy the consequences of the violation. $^{74}$

In recent years, remedial subsidiarity has become more and more under threat in the ECtHR's case-law, especially in the Court's struggle against the lack of enforcement of its judgments by domestic authorities. ${ }^{75}$ For mostly political reasons, this problem has not been remedied by the Committee of Ministers, although it is officially in charge of the ex post monitoring of the enforcement of the Court's judgments (art. 46(2) ECHR). In reaction, but also in prevention, therefore, the Court has started to specify States' remedial duties in its judgments. It has done so ex ante in its adverse judgments themselves, but has also started monitoring their enforcement ex post through its judgments on a second application pertaining to the same case. It has done the former, of course, in pilot judgments whose point is precisely to address structural problems in States Parties and to specify how they should go about resolving them in other cases. ${ }^{76}$ However, the Court has also specified individual and general remedial measures in other individual cases. ${ }^{77}$ As to ex post monitoring, the Court has started requiring States Parties that have established revision procedures under domestic law to use them after an adverse judgment by the Court. ${ }^{78}$

\section{Human Rights Subsidiarity Delineated}

Even when one focuses on their procedural or institutional dimensions, there are relations between international and domestic human rights institutions that

\footnotetext{
74 See Besson. "The 'Erga Omnes' Effect of Judgments of the European Court of Human Rights"; Lambert, The Execution of Judgments; Ruedin, L'exécution des arrêts.

75 See for a constructive critique, Helen Keller and Cedric Marti, "Reconceptualizing Implementation: The Judicialization of the Execution of the European Court of Human Rights' Judgments," European Journal of International Law 26 (2016): 829-50.

76 Hutten-Czapska v. Poland, ECHR 2006-VIII 57 (CE:ECHR:2006:0619JUD003501497), par. 232.

77 See Assanidze v. Georgia, ECHR 2004-II 221 (CE:ECHR:2004:0408JUD007150301).

78 See Verein gegen Tierfabriken Schweiz (VgT) v. Switzerland (no 2), ECHR 2009-IV 57 (CE:ECHR:2009:0630JUD003277202); Emre v. Switzerland (no 2), App no 5056/10 (ECtHR, 11 October 2011, CE:ECHR:2011:1011JUD000505610).
} 
should not be confused with relations of subsidiarity. A few delineations are in order, therefore.

First of all, human rights subsidiarity, especially in its procedural dimension, should not be conflated with the principles of litispendence and res judicata. These principles condition the jurisdiction of international human rights bodies and courts (e.g. art. 35(2)(b) ECHR). Unlike subsidiarity, they apply to the relationship between international bodies or courts themselves, and not to their relationship to domestic authorities.

Secondly, human rights subsidiarity, especially in its substantive dimension, requires deference to the review of domestic authorities. It should not be confused with the protection of the discretion of States in specifying and implementing human rights duties in their local circumstances in the first place. ${ }^{79}$ Human rights duties actually have to be specified in context depending on the concrete threats to the interest protected by the rights. ${ }^{80}$ As a result, States having jurisdiction over the right-holders are the only ones able to specify their own human rights duties in their respective domestic circumstances. ${ }^{81}$ This is actually why the margin of appreciation of States derived from human rights subsidiarity should not be too quickly identified with the "margin of appreciation" of States in general international law. ${ }^{82}$ The latter consists in their having discretion in the implementation of their international legal duties domestically. In the human rights context, that discretion is necessary, however, and cannot therefore amount to something that could be bypassed or reversed, whereas this would be the case were it to be equated with States' margin of appreciation and its potential limitations under the principle of subsidiarity.

Thirdly, human rights subsidiarity, especially in its substantive dimension, should not be confused with the stringency of human rights (duties). ${ }^{83}$ Substantive subsidiarity, and especially the margin of appreciation, implies adapting the degree of stringency of the ECtHR's scrutiny, but not of the duties arising from human rights themselves. These duties vary depending on the concrete

\footnotetext{
79 See also Letsas, "The Margin of Appreciation Revisited."

80 There is nothing about human rights discretion in the specification of human rights' duties that threatens their universality. On the contrary, the content of human rights' duties can only be specified by and in the domestic institutional context where they are owed and where the specific threats to the protected interests occur and can be identified. See also Føllesdal, "Appreciating the Margin of Appreciation"; Letsas, "The Margin of Appreciation Revisited"; Samantha Besson, "Justifications of Human Rights," in International Human Rights Law, $2^{\mathrm{d}}$ ed. Daniel Moeckli, Sangeeta Shah, and Sandesh Sivakumaran (Oxford: Oxford University Press, 2013), 34-52. Contra: Brems, "The Margin of Appreciation Doctrine"; Eyal Benvenisti, "Margin of Appreciation, Consensus, and Universal Standards," NYU Journal of International Law and Politics 31 (1999): 843-54. On the moral epistemology of human rights and their transnational legal practice, see Besson, "Human Rights as Transnational Constitutional Law."

${ }^{81}$ See Samantha Besson, "The Extra-territoriality of the European Convention on Human Rights. Why Human Rights Depend on Jurisdiction and What Jurisdiction Amounts to," Leiden Journal of International Law 25 (2012): 857-84.

82 Contra: Yuval Shany, "Towards a General Margin of Appreciation Doctrine in International Law?," European Journal of International Law 16 (2005): 907-40; Eirik Bjorge, "Been There, Done That: The Margin of Appreciation and International Law," Cambridge Journal of International and Comparative Law 4 (2015): 181-90.

83 See also Kratochvíl, "The Inflation of the Margin of Appreciation."
} 
threats to the human right at stake and the interest protected by the right. It does not depend on whether or not the ECtHR has the competence to review domestic authorities' decisions, on the one hand, and, more importantly, on what intensity of scrutiny it applies in that review, on the other. Of course, in practice, when the margin of appreciation applies to a case where the stringency of a duty is at stake, the lack of review or its limited scrutiny may be taken as an ex post confirmation of the domestic determination of the stringency of the duty.

Finally, human rights subsidiarity, especially in its substantive dimension, differs from principles of justification of a restriction on human rights, and in particular from proportionality. ${ }^{84}$ Human rights' restrictions may be deemed justified or not independently from the margin of appreciation of a State Party, and the latter does not constitute a justification for such a restriction. Hence the distinction made by George Letsas between the general (and correct) "procedural" or "structural" notion of the margin of appreciation, that is at stake in this article, and a more "substantive" one pertaining to the proportionality of a restriction that has nothing to do with it -and with human rights subsidiarity more generally. ${ }^{85}$ Of course, in practice, when the margin of appreciation applies to a case where a domestic restriction of human rights and its justifications are contested, the limited review by the international human rights body or court confirms the domestic justification of the restriction ex post and hence its assessment of proportionality, as a result.

\section{Human Rights Subsidiarity in Comparison}

Based on the proposed account of human rights subsidiarity in practice, we are now in a position to compare it with the various conceptions of subsidiarity one can identify in other contemporary political and legal contexts (a.). ${ }^{86}$ This comparison of various conceptions of subsidiarity is best done horizontally, i.e.,

\footnotetext{
${ }^{84}$ See Letsas, "Two Concepts of the Margin of Appreciation," 81-2; Christos L. Rozakis, "Through the Looking Glass: An 'Insider's' View of the Margin of Appreciation," in La Conscience des Droits: Mélanges en l'honneur de Jean-Paul Costa (Paris: LGDJ, 2011), 527-37.

${ }^{85}$ Ironically, Letsas's understanding of the "procedural" or "structural" margin of appreciation is usually captured as an application of "substantive" or "material" subsidiarity as it is understood here. This is because subsidiarity is always institutional and hence procedural to the extent that all its types pertain to the reviewing competence of international human rights institutions and courts (its existence, intensity and scope). For a critique of the term "substantive" to refer to subsidiarity, however, see Dubout, "La procéduralisation des droits."

86 Two caveats are in order. First, this article focuses solely on contemporary conceptions of subsidiarity. On the history of the principle in Greek and Medieval political thought, and in particular in the writings of Plato, Aristotle, Althusius, Aquinas or Kant, see e.g., Føllesdal, "The Principle of Subsidiarity as a Constitutional Principle in International Law"; Szymczak, "Rapport introductif: le principe de subsidiarité dans tous ses états"; Barroche, "Etat, libéralisme et christianisme"; John Finnis, Natural Law and Natural Rights, $2^{\mathrm{d}}$ ed. (Oxford: Oxford University Press, 2011). Second, the article focuses on the political or legal practice of subsidiarity, and not on its other social or religious uses. Of course, there are interesting historical ties to uncover between the different conceptions based on their genealogy (e.g., Barroche, "Subsidiarité"), but what matters here is the interpretation and justification of the contemporary legal principle of human rights subsidiarity by reference to the other contemporary legal conceptions of subsidiarity at play.
} 
through a comparative review and discussion of the different dimensions of subsidiarity across its various contexts (b.). ${ }^{87}$

The comparison of human rights subsidiarity with other conceptions of subsidiarity amounts to an exercise in (normative-) conceptual analysis and interpretation. ${ }^{88}$ What underpins this comparison is the presupposition that there actually is a single concept or principle of subsidiarity whose conceptions can differ along various dimensions. Instead, one could, of course, consider that the conceptions of subsidiarity at play in those different contexts are so diverse that they actually correspond to different concepts altogether. ${ }^{89}$ In this article, however, I consider that there is, besides common language, sufficient commonality (and not just enough agreement to disagree over subsidiarity!) in the different uses of subsidiarity to vindicate the proposed approach. 90

In a nutshell, what seems to be common to all the conceptions of subsidiarity is the minimal two-pronged principle that, first of all, the individual/smaller/lower/ internal unit or entity should have priority (or so-called "primarity") in doing certain things and that, secondly, this priority may or should be reversed only when the individual/smaller/lower/internal unit or entity cannot do so, or not sufficiently well, and/or when the collective/larger/higher/external one can do so better. This minimal understanding captures (i) the two-step functioning of subsidiarity and (ii) its two-party or relational structure. ${ }^{91}$ For the rest, depending on the various dimensions of subsidiarity selected, and on their multifarious potential combinations across contexts or even in a single context, the different conceptions of the principle can vary hugely, as we will see.

Of course, the existence of a minimal common concept of subsidiarity does not mean that what goes by the name of subsidiarity in international human rights law actually is a form of subsidiarity. It is the aim of this section, therefore, to assess, by normative-conceptual comparison, whether the minimal two-pronged concept of subsidiarity is at play in the three types of human rights subsidiarity identified in the previous section from practice, on the one hand, and to what extent its conception differs from conceptions of subsidiarity we know from other legal and political contexts, on the other.

\footnotetext{
87 Instead, other studies of subsidiarity in general or in the human rights context have chosen a vertical approach, context by context or conception by conception. See e.g., Mowbray, "Subsidiarity and the European Convention on Human Rights"; Føllesdal, "The Principle of Subsidiarity as a Constitutional Principle in International Law"; Barber, "The Limited Modesty of Subsidiarity." As I will argue, however, the various dimensions of subsidiarity can be mixed and matched in so many different ways that it is difficult to identify a single conception at play in one single context and it is better therefore to unpack these conceptions into their different dimensions.

88 On the analysis of normative concepts and especially moral and legal ones like subsidiarity, see also Ronald Dworkin, Law's Empire (London: Fontana Press, 1986).

${ }^{89}$ I thank Leslie Green for this point.

${ }^{90}$ See also Føllesdal, "The Principle of Subsidiarity as a Constitutional Principle in International Law"; Barber, "The Limited Modesty of Subsidiarity," 309.

${ }^{91}$ It should in particular cover both functional and territorial uses of subsidiarity depending on whether the units or entities are territorially delimited or merely functional ones.
} 


\section{A. Contexts of Subsidiarity}

The principle of subsidiarity may be encountered in a great variety of political and legal, and hence institutional contexts. To some extent albeit not exclusively, ${ }^{92}$ these contexts determine some of the other dimensions of subsidiarity and should be discussed first, therefore.

Among contemporary contexts of subsidiarity, the eldest conception of the principle of subsidiarity, as it is currently used, may be traced back to the Catholic Church's social doctrine of subsidiarity (subsidiarii officii principium). The Catholic social doctrine of subsidiarity now also applies by extension to any forms of social and political governance-and even arguably only to them and not the Church itself. It considers that individuals or the smaller groups (e.g., a family) in a social or political body should be the ones deciding on their interests and acting, including and mainly against State intervention. ${ }^{93} \mathrm{~A}$ second context of subsidiarity is one of technical-economic organization, inspired by the $19^{\text {th }}$ Century liberal doctrine. In that context, subsidiarity becomes a utilitarian principle of organization according to which the local level of decision-making maximizes efficiency. ${ }^{94} \mathrm{~A}$ third context is that of federal polities, whether national or supranational, and hence a political form or organization. ${ }^{95}$ This is clearly the case of subsidiarity in the post-war traditions of federalism prevailing in Germany and Switzerland. A fourth context of subsidiarity, that is related to all the former, is the EU's (art. 5(3) TEU), and hence an integrated and supranational political and legal order. ${ }^{96}$ Finally, at least for now, a fifth context is that of international legal regimes and/or institutions that exercise public authority over individuals such as WTO law or environmental law, and hence supranational legal regimes. ${ }^{97}$

92 There are hybrid conceptions of subsidiarity, of course, and some dimensions may overlap between its conceptions. Thus, the German federalist doctrine of subsidiarity has been influenced by Catholic social doctrine; Catholic social doctrine has transformed from a form of Aristotelian naturalism into a modern kind of jusnaturalism in the context of its application to human rights in the $20^{\text {th }}$ Century; EU law subsidiarity is a combination of German federalist subsidiarity and liberalorganizational subsidiarity; and so on. See also Barroche, "Subsidiarité."

${ }_{93}$ See e.g., Chantal Million-Delsol, L'Etat subsidiaire (Paris: PUF, 2010); Finnis, Natural Law and Natural Rights, 146-47. See also in the ECHR context, Maria Cahill, "The Origin of AntiSubsidiarity Trends in the Regulation of the Family," International Journal of the Jurisprudence of the Family 4 (2013): 85-114.

94 See e.g., Willem Molle, The Economics of European Integration-Theory, Practice, Policy, $4^{\text {th }}$ ed. (London: Ashgate, 2001), 23-5. See also Barroche, Etat, libéralisme et christianisme, 563.

95 See e.g., Daniel Halberstam, "Federal powers and the principle of subsidiarity," in Global Perspectives on Constitutional Law, ed. Vikram Amar and Mark Tushnet (New York: Oxford University Press, 2009), 34-47.

${ }^{6}$ See e.g., Vlad Constantinesco, "Le principe de subsidiarité: un passage obligé vers l'Union européenne?," in L'Europe et le droit. Mélanges en hommage à Jean Boulouis, (Paris: Dalloz, 1991), 35-45; Renaud Dehousse, "La subsidiarité et ses limites," in Annuaire européen, vol. 40 (Dordrecht: Martinus Nijhoff, 1992), 27-46; Antonio Estella, The European Union Principle of Subsidiarity and its Critique (Oxford: Oxford University Press, 2002); Barber, "The Limited Modesty of Subsidiarity."

97 See e.g., Benvenisti, "Margin of Appreciation, Consensus, and Universal Standards"; Shany, "Towards a General Margin of Appreciation Doctrine in International Law?"; Bjorge, "The Margin of Appreciation and International Law"; Alexia Herwig, "Federalism, the EU and International Law: on the Possible (and Necessary) Role of Subsidiarity in Legitimate Multilevel Trade Governance," in Federalism in the European Union, ed. Elke Cloots, Geert De Baere, Stefan Sottiaux (Oxford: Hart Publishing, 2012), 65-82. 
Human rights law may be compared with the other contexts of subsidiarity to the extent that, like them, it has both a legal and an institutional context. Subsidiarity applies to the ECHR, for instance, and especially to its implementation by domestic institutions, whether legislative, executive or judicial, on the one hand, and the ECtHR, on the other. Importantly, however, the ECHR is not an autonomous legal system or order. Nor is there an independent polity (e.g., the Council of Europe's) constituted by it. To that extent, the context of human rights subsidiarity is not that of an encompassing legal or political system including different equivalent units albeit at different levels of decision-making. Human rights subsidiarity differs therefore in this fundamental respect from subsidiarity in EU law or in a federal entity or order.

\section{B. Dimensions of Subsidiarity}

The different dimensions of subsidiarity used to develop a normative-conceptual analysis and interpretation of human rights subsidiarity in this section are: its subjects (i.), objects (ii.), functions (iii.), justifications (iv.) tests (v.), limits (vi.), and review (vii.).

\section{i. Subjects of Subsidiarity}

The two relevant subjects or units of subsidiarity can vary a lot from one conception of subsidiarity to the next. They actually differ between contexts of subsidiarity, even though the relevant subjects need not be mutually exclusive and may overlap within each context.

First of all, subjects of subsidiarity can be States, but also sub-national or supranational political entities in general. This is clearly the case in the federal context where subsidiarity applies between the federal State, or central political entity, and the federated entities or provinces/States. It is also the case in the EU where subsidiarity applies between the EU and its Member States. Secondly, subjects of subsidiarity may be individuals or groups of individuals (e.g., a family). This is the case in the Catholic social doctrine of subsidiarity ${ }^{98}$ or in certain liberal-economic doctrines of subsidiarity. Finally, subjects of subsidiarity may be institutions, and especially courts or monitoring bodies within a State or political entity or even outside them. This is the case in the international legal context where subsidiarity is usually applied to international judicial or monitoring bodies of some kind independently from their belonging to a larger political unit.

Human rights subsidiarity does not apply between States or political entities or between institutions inside a State or political entity, or at least not only. It applies, more precisely, between States and their legislative, executive or judicial institutions, and mostly the latter actually, on the one hand, and international human rights monitoring bodies, whether judicial or political, and mostly judicial actually, on the other. Thus, it may encompass a relationship between a domestic

\footnotetext{
98 See e.g., Finnis, Natural Law and Natural Rights, 146-7; Cahill, "The Origin of Anti-Subsidiarity Trends."
} 
judge and an international judge, but not only. Most of the time, it is a relationship between a domestic authority in general with an international judge. ${ }^{99}$ For instance, the ECtHR refers to the subjects of subsidiarity being, on the one hand, the "Convention mechanism" or the "international machinery of collective enforcement established by the Convention" and, on the other, "national authorities". ${ }^{100}$ Importantly, in 2009, the Court stressed in $A$ and Others $v$. United Kingdom that substantive subsidiarity does not transpose onto the domestic legal order and does not therefore apply to relations between domestic authorities. Indeed, "the doctrine of the margin of appreciation has been meant as a tool to define relations between the domestic authorities and the Court. It cannot have the same application to the relations between the organs of State at the domestic level." 101

Finally, human rights subsidiarity does not apply to individuals or groups of individuals (e.g., the family). It may do so by extension, of course, in particular through the discretion of States in their domestic implementation of positive human rights duties in private contexts such as family life or the economic sector. However, when it does, it is only an indirect consequence that depends on States' own political and constitutional traditions and in particular on whether or not the latter recognizes individuals or groups of individuals as subjects of subsidiarity. Such an application of subsidiarity to individuals or groups of individuals does not directly flow from international human rights law; the latter only binds States and international human rights bodies' or courts' review only pertains to States' implementation of human rights and their respective review of that implementation. ${ }^{102}$ As a result, human rights subsidiarity applies exclusively to States and their relations to international monitoring bodies or courts.

Of course, human rights are rights of individuals (and, sometimes, groups of individuals). To that extent, some may conclude to their being the primary subjects of subsidiarity. This is, at least, what some human rights theorists working in the field of Catholic social doctrine could argue. ${ }^{103}$ However, human rights are equal rights that are owed qua human rights duties by all right-holders together as a political community of public equals, i.e., the democratic State. This explains in turn why human rights duty-bearers can and should only be institutional and, actually, democratic-political entities. ${ }^{104}$ There can and should be no horizontal

\footnotetext{
99 See e.g., Animal Defenders International v. United Kingdom, par. 115-116.

100 See SAS v. France, par. 129; Case "relating to certain aspects of the laws on the use of languages in education in Belgium" v. Belgium, par. 10.

101 See $A$ and Others $v$. United Kingdom, par. 184.

102 See, however, the dissenting opinions of Judges Zupancic, Gyulumyan, Kalaydjieva, De Gaetano and Wojtyczek in O'Keeffe v. Ireland, ECHR 2014 (not published yet) (CE:ECHR:2014:0128 JUD003581009), par. 7 and the concurring opinion (but on other grounds) of Judge Wojtyczek in Sindicatul 'Pastorul Cel Bun' v. Romania, ECHR 2013-V 41 (CE:ECHR:2013:0709 JUD000233009), par. 2. For a discussion of this recent trend, see Mowbray, "Subsidiarity and the European Convention on Human Rights."

103 See e.g., Cahill, "The Origin of Anti-Subsidiarity Trends," 112-3; Shelton, "Subsidiarity and Human Rights Law,” 10-11.

104 See e.g., HRC, General Comment No 26 on Continuity of Obligations, UN Doc CCPR/C/21/ Rev.1/Add.8/Rev. 1 (1997), par. 4. See Samantha Besson, "The Bearers of Human Rights' Duties and Responsibilities for Human Rights: A Quiet (R)Evolution?," Social Philosophy \& Policy 32
} 
effect of human rights and no private duties arising from them, as a result. To that extent, there is no place in human rights subsidiarity for non-institutional subjects, and hence for individuals' own determination and supervision of their human rights or, for that matter, for private groups' such as families or churches other than the State. It would actually be paradoxical to want to apply the antiStatist traits of some versions of the Catholic social doctrine of subsidiarity ${ }^{105}$ to human rights subsidiarity. The latter's main object of protection is indeed Statebased implementation of human rights.

\section{ii. Objects of Subsidiarity}

The objects of subsidiarity can be of different kinds. They actually vary a lot from one context to the next, even though the different objects need not be mutually exclusive and may overlap.

First of all, subsidiarity may pertain to sovereignty or political autonomy. This is the case when sovereignty is understood as an ensemble of competences or powers. A second and more common object of subsidiarity is authority or the claim to rule, and sometimes even legitimate authority and the right to rule. In the latter case, subsidiarity can actually work as a justification of authority, as we will see. This application of subsidiarity to authority is common in the federal context, although it need not necessarily work as a justification of authority. A third and even more common object of subsidiarity consists in powers or competences, of a legislative, executive or judicial kind, provided they are not exclusively pre-allocated. This is the object of subsidiarity under art. 5(3) TEU. A fourth object of subsidiarity can be law itself, including legal duties and responsibilities. Finally, a fifth object of subsidiarity can be any aim or objective.

In the context of human rights subsidiarity, there is no sovereignty or authority at stake, unlike what applies in the context of autonomous legal and political systems like the EU or a federal State. Rather, the object of subsidiarity is a (judicial or not) competence or power to monitor or review. International human rights monitoring institutions do not indeed have any other competence to specify and implement human rights for this is exclusively a domestic competence. This applies at least to the international side of subsidiarity, for the domestic object of subsidiarity can be any legislative, executive or judicial activity and extends beyond monitoring or review. A first conclusion then is that human rights subsidiarity is not strictly a matter of delineating international from domestic (judicial) reviewing competence. It pertains rather to the relationship between a complete institutional competence regarding human rights at domestic level, on the one hand, and an international monitoring or reviewing competence, on the other.

As a matter of fact, strictly speaking, human rights subsidiarity may not be solely a matter of (review) competence. Indeed, international human rights law

(2015): 244-268; Samantha Besson, "The Allocation of Anti-poverty Rights Duties-Our Rights, but Whose Duties?," in Poverty and the International Economic Legal System-Duties to the World's Poor, ed. Krista Nadakavukaren Schefer (Cambridge: Cambridge University Press, 2013), 408-31. 105 See Barroche, "Subsidiarité." 
does not pertain to vesting domestic institutions with competences. It is rather about generating duties and responsibilities to the extent that domestic institutions have a general positive duty to organize themselves so as to be able to exercise their legislative, executive or judicial activities to implement their specific human rights duties. Of course, this includes a duty for them to set up domestic judicial review and grant the latter reviewing competences under domestic human rights law (e.g., art. 13 ECHR). Importantly, however, this does not, conversely, turn human rights subsidiarity into a subsidiarity of duties or responsibilities where some would be "primary" and others "secondary," and human rights responsibilities would merely be devolved to international institutions when subsidiarity applies. There are no human rights duties or responsibilities of international human rights institutions stricto sensu.

So, this makes for an interesting contrasted object of human rights subsidiarity: an international judicial or institutional monitoring or reviewing competence, on the one hand, and a domestic positive duty to respect and protect human rights that includes a duty to allocate a domestic judicial competence of decision and review, on the other. As a result, human rights subsidiarity is not about either competences $^{106}$ or responsibilities ${ }^{107}$ only.

\section{iii. Functions of Subsidiarity}

The functions of subsidiarity can be of different kinds. They actually vary a lot from one context to the other and may be in tension with one another, even though the different functions need not be mutually exclusive and may overlap.

First of all, subsidiarity may be about providing justification or title, and in particular constitute a ground for the legitimacy of authority or competences. This justificatory function of subsidiarity applies in the context of Catholic social doctrine, for instance. Of course, at a minimum and qua principle, subsidiarity always has a normative function, giving rise to rights, duties, liabilities or powers of the subjects of subsidiarity.

Secondly, subsidiarity may have as a function to allocate its objects, whether authority or competences. It is the case, in particular, in the federal context where competences, that are not exclusively pre-allocated, get allocated concretely in each case by reference to subsidiarity. Subsidiarity in its allocating function may be transitive and work both ways (upwards and downwards, as it were) or be downwards only, depending on whether it is only the collective/larger/higher/ external unit that abides by it or both that one and the individual/smaller/ lower/internal one. In most cases, it will be restricted to the unidirectional upwards allocation of competence. The downwards direction is often described as the deferral or devolution of competences; it actually comes closer to decentralization (that is another feature of federalism) than to subsidiarity. ${ }^{108} \mathrm{~A}$ third function of subsidiarity also pertains to competences, but instead of allocating

106 Contra: Fabbrini, "The Margin of Appreciation and the Principle of Subsidiarity: A Comparison."

107 Contra: Spielmann, "Whither the Margin of Appreciation?"

108 See Barroche, "Subsidiarité." 
them, subsidiarity regulates their exercise. This is the function of subsidiarity in EU law in cases where the EU is not exclusively competent and where both the EU and its Member States share a competence. Again, both a unidirectional and a bidirectional approach may be taken depending on the cases, although it is usually unidirectional and upwards in direction.

Finally, subsidiarity's function may be to sequence the exercise of a competence or duty. In such cases, there is no allocation to either of the two subjects of subsidiarity, since both of them have and exercise the competence or duty at stake, but do so in a given order and to a given degree. What subsidiarity does, when it sequences, is set the order and degree in and to which both subjects decide, giving the priority to one over the other albeit allowing both to decide in a complementary fashion in the end, unless the priority is reversed and the collective/larger/higher/external subject is allowed to decide, either first or all over again.

Importantly, there are many different normative implications of subsidiarity in those different functions. An important distinction is between subsidiarity working as a Hohfeldian power/disability pair and subsidiarity working as one may refer to as a duty/privilege pair. In the former case, when the priority of the individual/smaller/lower/internal unit is reversed in favor of the collective/ larger/higher/external one, the power/disability opposition is flipped. In the latter case, however, subsidiarity gives rise to a duty of the collective/larger/ higher/external unit when the priority of the individual/smaller/lower/internal one is reversed. This distinction is often captured as one between "negative" and "positive" subsidiarity depending on whether the reversal of priority gives rise to a power or to an actual duty. The former is the most common one, especially present in the liberal-organizational theories discussed before and according to which any social or political intervention is resisted. The latter, by contrast, is used in some Catholic doctrines of subsidiarity that regard social or political intervention as potentially beneficial to individual autonomy. ${ }^{109}$ Note that this positive/negative subsidiarity distinction should not be conflated with another one that pertains to the subsidiarity test, as I will explain next. There, a distinction is drawn between the individual/smaller/lower/internal unit being unable to decide (negative test) and the collective/larger/higher/external unit being able to do so (positive test). In some versions of subsidiarity, both are needed, as in EU law. In most cases, however, the negative test is the sole one to lead to the reversal of priority. Finally, one often encounters a third use of the distinction between negative and positive subsidiarity: it captures the opposition between the priority of domestic authorities and the reversal of that priority in favor of international ones as one between the negative and positive dimensions of subsidiarity. ${ }^{110}$

The function of human rights subsidiarity is primarily the sequencing of a judicial monitoring or reviewing competence, and not the allocation of a single competence to review or of the exercise of that competence. Indeed, even when subsidiarity applies, both domestic and international human rights institutions

109 See e.g., Shelton, "Subsidiarity and Human Rights Law," 5.

110 See e.g., Barroche, "Subsidiarité." 
and/or courts are competent to review and can actually exercise their competences in all cases (provided an individual applicant makes an application). However, what subsidiarity requires is that international human rights institutions exercise their competence to review only once domestic remedies have been exhausted (procedural subsidiarity; sequencing in exercise) and only to a limited degree and scope (substantive and remedial subsidiarity; sequencing in degree and content). This explains why some authors refer to human rights subsidiarity as "complementary subsidiarity" as opposed to "competitive subsidiarity" which is most common among other conceptions of subsidiarity. ${ }^{111}$ This association of human rights subsidiarity with complementarity actually fits the complementarity of the functions of international human rights law presented in the first section. ${ }^{12}$ It also corresponds better to the Latin concept of subsidium which implies help or assistance rather than subordination or secondariness. ${ }^{113}$

Importantly, whether human rights subsidiarity pertains to sequencing the exercise of judicial reviewing competences or their degree, it is unidirectional and downwards only. It cannot be used by domestic authorities or courts to defer the exercise of their review to international human rights institutions or courts. The former are presumed to know better what the local circumstances are and this is what is needed to specify and apply human rights. However, and it is related, there is no positive test or second prong in the test of effectiveness to the extent that the international human rights' body or court is presumed to have the capacity to complement and assist once it has the power to do so.

\section{iv. Justifications of Subsidiarity}

The justifications of subsidiarity can be of different kinds. They actually vary a lot from one context to the next and may even be in tension with one another, even though the different justifications need not be mutually exclusive and may overlap. The justification of the principle of subsidiarity amounts to its source or the reasons for having that principle. ${ }^{114}$

111 See e.g., Joël Andriantsimbazovina, "La subsidiarité devant la Cour de justice des Communautés européennes et de la Cour européenne des droits de l'homme," Revue des affaires européennes 1-2 (1998): 28-9; Szymczak, "Rapport introductif: le principe de subsidiarité dans tous ses états," 27. 112 Identifying subsidiarity and complementarity may be a source of confusion for international lawyers, however, given how the latter is used in international criminal law to preclude endorsing a subsidiarity-like exhaustion of local remedies and to adopt an either/or approach to criminal jurisdiction. This is actually paradoxical because the either/or allocation of judicial competence through "complementarity" in international criminal law comes closer to the function of other conceptions of subsidiarity than it does to the ones of human rights subsidiarity. Retrospectively, it is a shame therefore that, because art. 1 of the 1998 Rome Statute was drafted well after the term "subsidiarity" had been chosen in EU and ECHR law, the term "complementarity" was chosen instead (see e.g. https://www.icc-cpi.int/iccdocs/doc/doc1575650.pdf, par. 47).

113 On the etymology of the $20^{\text {th }}$ Century substantive term "subsidiarity" (in German, French and English), see Barroche, "Subsidiarité."

114 When the function of subsidiarity is normative and is therefore to justify its object (authority, competences or duties and their allocation), as discussed before, the justifications of the principle of subsidiarity become justifications of justifications, as it were, and hence potentially regressive. Such justificatory regresses are not unknown in morality, however, and especially among intermediary principles. This actually includes many other principles within international human rights law, such 
A first justification for the principle of subsidiarity can be individual autonomy (and, by extension, human well-being) that requires being able to participate when one can. ${ }^{115}$ This is a justification one encounters in the context of the Catholic social doctrine of subsidiarity, although other justifications such as epistemic or democratic ones, presumably by derivation, are often put forward in that context too. ${ }^{116}$

A second justification that turns the first one into a more collective one is selfdetermination, ${ }^{117}$ and the protection against tyranny. It is difficult to see how selfdetermination alone could justify the priority of the individual/smaller/lower/ internal unit, however, for the size of the unit is irrelevant to self-determination. Accordingly, a variation of this justification one often encounters, thirdly, is cultural or national identity. This is a justification one finds in the federal context, and especially the multinational or multicultural political context. ${ }^{118}$ Fourthly, democratic sovereignty or democracy in general is often mentioned as an additional qualification or a justification of subsidiarity in the collective and political context. More specifically, it is the democratic requirement that those who are most affected by a decision should be included in the decision-making process that is invoked to justify subsidiarity. Another democratic argument is egalitarian, however, and has to do with choosing the decision-making unit that gives people the most voice. ${ }^{119}$ Of course, as many authors have argued, democracy alone cannot constitute an argument for the relevant decision-making unit in a given polity ${ }^{120}$ and, by extension, for subsidiarity qua allocating or sequencing principle between the relevant units. ${ }^{121}$ Interestingly, the second, third and fourth justifications are all collective variations of the first justification of subsidiarity, i.e., individual autonomy or self-determination.

A fifth, and very different, justification for subsidiarity is the maximization of economic efficiency. This is the justification for subsidiarity one encounters in the liberal-organizational approach. A final justification is epistemic capacity. This is shared by other justifications and present in many conceptions of subsidiarity, including in the liberal-economic approach, the federal context or even EU law, where the justification for the priority of the domestic exercise of competences is that domestic authorities know better.

as proportionality, for instance. See on human rights as relations of justification, Besson, "Justifications of Human Rights."

115 See e.g., Finnis, Natural Law and Natural Rights, 146-7 and 169 ("the principle of subsidiarity is a principle of justice”).

116 See e.g., Shelton, "Subsidiarity and Human Rights Law," 5-7. This combination of democratic and personalist justifications for subsidiarity, especially in favor of personal autonomy, may also be found in Judge Wojtyczek's opinion in Sindicatul 'Pastorul Cel Bun' v. Romania, par. 2.

117 See e.g., Shelton, "Subsidiarity and Human Rights Law," 5.

118 For a critique, see Barber, "The Limited Modesty of Subsidiarity."

119 See e.g., Shelton, "Subsidiarity and Human Rights Law," 6.

120 See e.g., Frederick G. Whelan, "Prologue: Democratic Theory and the Boundary Problem," in Nomos XXV: Liberal Democracy, ed. J. Roland Pennick and John W. Chapman (New York: NYU Press, 1983), 13-47.

${ }^{121}$ See Barber, "The Limited Modesty of Subsidiarity"; Føllesdal, "The Principle of Subsidiarity as a Constitutional Principle in International Law." 
In international human rights law, justifications brought forward for human rights subsidiarity tend to be two-fold: epistemic and democratic. This is has been confirmed by the ECtHR that refers to domestic authorities' being "better placed than an international court to evaluate local needs and conditions", on the one hand, and to reasonable disagreement and the special weight that should be given accordingly to the democratic domestic policy-maker, on the other. ${ }^{122}$ This combination of justifications for human rights subsidiarity is interesting because it reveals a certain ambivalence between an organizational approach and a more normative one regarding the object, the function and the test of human rights subsidiarity. ${ }^{123}$ This ambivalence may be explained by the multiple combinations of conceptions of subsidiarity at play in Europe across different contexts and, arguably, within the same one like the EU. From a democratic theory perspective, however, the combination is not surprising in the light of the epistemic justifications often put forward for democratic procedures themselves. ${ }^{124}$ The epistemic justification is even stronger in the human rights case given the concrete nature of human rights duties whose content can only be specified in domestic circumstances; this is the only context in which the threats to the interest protected by a given human right can be assessed and the potential corresponding duties and their egalitarian dimensions identified. ${ }^{125}$ As I explained before, however, the test for the effectiveness of the minimal human rights' protection is not epistemic to the extent that the domestic authorities are presumed to know better and that the second prong of the principle of human rights' subsidiarity does not entail a positive condition that the international human rights' body or court can better protect them.

Importantly, the democratic justification of human rights subsidiarity should not be mistaken with other democratic justifications of subsidiarity. ${ }^{126}$ To that extent, it does not fall prey to the criticism made to the latter either. Because, as I explained before, human rights subsidiarity does not apply to competing political entities, democratic subsidiarity is not a matter of giving priority to one over the other depending on how well they contribute to the protection of either equality or the all-affected principle. There is only one political entity whose democracy is at stake in the human rights context, and it is that of every State implementing international human rights law. What justifies sequencing the monitoring or reviewing competence of an international human rights body or court is not its democratic credentials as a court, therefore: it is not the body or court of a more

122 See SAS v. France, par. 129.

123 See Dubout, "La procéduralisation des droits." See also Barber, "The Limited Modesty of Subsidiarity" with respect to subsidiarity in EU law.

124 See e.g., José L. Martí, "The epistemic conception of deliberative democracy defended: reasons, rightness and equal political autonomy," in Deliberative Democracy and Its Discontents, ed. José Luis Martí, Samantha Besson (Aldershot: Ashgate, 2006), 27-56.

125 See Besson, "The Allocation of Anti-poverty Rights Duties-Our Rights, but Whose Duties?"; Samantha Besson, "The Egalitarian Dimension of Human Rights," Archiv für Sozial- und Rechtsphilosophie Beiheft 136 (2012): 19-52.

126 Contra: Shelton, "Subsidiarity and Human Rights Law," 6-7. 
encompassing democratic polity. ${ }^{127}$ On the contrary, what justifies its complementary review and limited intensity is the protection of domestic democracyand, as a matter of fact, of human rights themselves, as I will explain.

Indeed, and more specifically, the democratic justification of human rights subsidiarity resides in well-known mutual relationships in constitutional theory: the mutual or constitutive relationship between human rights and democracy, one the one hand, and between human rights, democracy and judicial review, on the other. The additional complexity in international human rights law is that, among the three elements in the triangle, human rights and judicial review are both domestic and international, while democracy remains solely national. ${ }^{128}$

First of all, the relationship between democracy and human rights. It is the egalitarian dimension of human rights qua rights of everyone and, conversely, the human rights-constituted nature of basic equality that explains how human rights and equality are mutually constitutive. In turn, because democracy is grounded in equality, having a democratic regime is a requirement of human rights by virtue of the mutuality of constitution between human rights and equality. ${ }^{129}$

The mutuality between human rights and equality, and its implications for the relationship between human rights and democracy account for two movements one may observe in international human rights law. First of all, they explain why human rights should be identified and specified through egalitarian and hence democratic procedures. This is actually confirmed by international human rights law and its requirement that States be organized democratically. Thus, the ECHR's Preamble refers to the reliance of human rights protection on "effective political democracy." The ECtHR's case-law itself states that democracy and, to date, domestic democracy is the only regime where the equality of human rightsholders can be respected. ${ }^{130}$ The relationship between democracy and human rights also accounts for why the latter may be restricted solely through democratic procedures and by reference to equality as emphasized, for instance, by the conditions of restriction of the par. 2 of art. 8-11 ECHR. Secondly, and conversely, human rights should also work as a way to set egalitarian limits on democracy. A confirmation of this may be found in both non-discrimination rights and the fundamental core of each human right, for they protect the basic equality of individuals against restrictions through democratic decisions.

Where does international human rights law fit into this picture of mutual constitution between democracy and human rights? As I argued before, its role is complementary and minimal, and not redundant to that of domestic human

\footnotetext{
127 On supranational human rights review and its differences from domestic constitutional review from a democratic perspective, see Samantha Besson, "European Human Rights, Supranational Judicial Review and Democracy-Thinking Outside the Judicial Box," in Popelier et al., Human Rights Protection in the European Legal Order: Interaction between European Courts and National Courts, 97-145.

128 See Samantha Besson, "Human Rights and Democracy in a Global Context-Decoupling and Recoupling," Ethics and Global Politics 4 (2011): 19-50.

129 See Besson, "The Egalitarian Dimension of Human Rights."

130 See e.g., ZZdanoka v. Latvia, ECHR 2006-IV 29 (CE:ECHR:2006:0316JUD005827800), par. 98; Baczkowski and others v. Poland, App no 1543/06 (ECtHR, 3 May 2007, CE:ECHR:2007:0503 JUD000154306), par. 61.
} 
rights law. It protects and entrenches an external and minimal guarantee of both democracy and human rights from outside the democratic polity. International human rights law protects "the right to have human rights" domestically. ${ }^{131}$ To that extent, its guarantees are substantively subsidiary to domestic human rights law; the latter is developed and interpreted democratically before it becomes sufficiently transnational to be entrenched as an international standard and to bind domestic human rights law in return. ${ }^{132}$

Second, the relationship between human rights, democracy and judicial review. Given the mutual constitution and tension between democracy and human rights, constitutional review has developed as a way to protect both basic equality and the human rights that constitute it. It protects equality and human rights against the proceduralization of equality through democratic procedures, on the one hand, and, conversely, equality and democracy against the essentialization of human rights, on the other. It is by no means an easy balance to preserve, but constitutional review is the mechanism constitutional democracy has developed to protect equality. This explains why setting up domestic mechanisms of judicial review of domestic law, including democratic legislation of course, is actually a requirement of international human rights law as exemplified by art. 13 ECHR. This is also one of the background conditions for the application of subsidiarity and the sequential "primarity" of domestic review, as I explained before.

Where does international human rights institutions or courts' review fit into this picture of mutual constitution between human rights, democracy and judicial review? Like international human rights law, its role is complementary and minimal. It ensures an external review of the domestic review that occurs outside of the democratic polity, and to that extent is substantively and procedurally subsidiary to domestic human rights adjudication that is democratically embedded through the separation of powers. This relationship between art. 13 ECHR and the primary domestic duty to organize domestic judicial review of domestic human rights implementation, on the one hand, and the subsidiarity of the competence of judicial review of the ECtHR, on the other, has been stressed many times by the Court itself. ${ }^{133}$ International or supranational judicial review in the human rights context should not therefore be equated with antimajoritarian judicial review in a domestic constitutional democracy. ${ }^{134}$

In sum, human rights subsidiarity finds its justification in the egalitarian and hence democratic dimension of human rights, and as a result in human rights

131 See Besson, "Human Rights and Constitutional Law"; Besson, "Human Rights and Democracy in a Global Context."

132 Of course, human rights are what institutions say they are and the difference between domestic and international human rights law is actually one between their institutional interpretations by domestic and international human rights courts and bodies. See also Hessler, "Resolving Interpretive Conflicts in International Human Rights Law"; Samantha Besson, "The Legitimate Authority of International Human Rights: On the Reciprocal Legitimation of Domestic and International Human Rights," in The Legitimacy of International Human Rights Regimes, ed. Andreas Føllesdal, Johan Karlsson Schaffer, Geir Ulfstein (Cambridge: Cambridge University Press, 2013), 32-83.

133 Vučkovic and Others v. Serbia, par. 69; Kudla v. Poland, par. 148 and 155.

134 See also Besson, "European Human Rights, Supranational Judicial Review and Democracy." Contra: Føllesdal, "Appreciating the Margin of Appreciation"; Benvenisti, "Margin of Appreciation, Consensus, and Universal Standards." 
themselves. ${ }^{135}$ This egalitarian justification of subsidiarity explains how central the principle of subsidiarity has become in international human rights law. It also explains why it is a self-standing jurisprudential principle within ECHR law and one that has grown out of the ECtHR's case-law. Rather than revert to equality and democracy every time, it has been easier for the Court to identify a middleground, structural or organizational principle like subsidiarity to capture the institutional or structural consequences of the human rights-equality-democracy triangle for its power of review.

Interestingly, the democratic justification of human rights subsidiarity explains how the closer a human rights issue pertains to democracy, the more important subsidiarity becomes, and especially substantive subsidiarity. This is confirmed by the international human rights practice, and in particular the ECtHR's low level of scrutiny in matters pertaining to political matters in general. ${ }^{136}$ More generally, the importance of the existence or emergence of a European transnational consensus for the reduction of the margin of appreciation corresponds to the recognition of the importance of the democratic implementation and development of human rights in all European States. Hence the link made repeatedly by the ECtHR between reasonable disagreement and the margin of appreciation of domestic democratic authorities. ${ }^{137}$ Conversely, the democratic justification of human rights subsidiarity also accounts for the inherent democracy-based and egalitarian limitations to subsidiarity, in particular to the margin of appreciation, and especially non-discrimination rights or the inner or fundamental egalitarian core of each human right. ${ }^{138}$

\section{v. Tests of Subsidiarity}

The tests or criteria of subsidiarity can be of different kinds. They actually vary a lot from one context to the other and especially from one justification to the other and may be in tension with one another, even though the different tests need not be mutually exclusive and may overlap.

In short, the subsidiarity test, when negative, leads to the reversal of the priority of the individual/smaller/lower/internal unit or entity in favor of the collective/ larger/higher/external one. The primary and most widespread test is one of effectiveness. The point of the test is to assess the ability of the individual/lower/ smaller/internal unit to fulfill its duties, reach its objectives (e.g., art. 5(3) TEU)

135 Unlike Letsas, "The Margin of Appreciation Revisited," I do not see that the margin of appreciation and the ECtHR's deference to domestic authorities undermine the egalitarian dimension of human rights, which I endorse like him. Reasonable disagreement about our human rights, and hence about what makes us equal, calls for the democratic determination of our rights. So, the difference between his account and mine resides in the relationship I see between human rights (and equality) and democracy (and by extension judicial review). See also Besson, "European Human Rights, Supranational Judicial Review and Democracy"; Besson, "The Egalitarian Dimension of Human Rights."

136 See e.g., Baczkowski and others v. Poland, par. 61; Refah Partisi v. Turkey, ECHR 2003-II 267 (CE:ECHR:2003:0213JUD004134098); Mathieu-Mohin Clerfayt v. Belgium; ECHR (1987) Series A no 113 (CE:ECHR:1987:0302JUD000926781); Sitaropoulos and Giakoumopoulos v. Greece.

137 See SAS v. France, par. 129.

138 See e.g., Sejdić and Finci v. Bosnia and Herzegovina, ECHR 2009-VI 273 (CE:ECHR:2009:1222 JUD002799606). 
or implement its competences. This test is, of course, largely empty and needs to be filled in by reference to the object of subsidiarity (e.g., specific duties, objectives or competences). The full realization or effectiveness of most of them remain largely indeterminate, however, and their determination a matter of appreciation. This then passes the buck of the test of subsidiarity back to its justification to flesh out the criterion of effectiveness. Effectiveness is the subsidiarity test that applies in EU law, and this explains an important part of the criticism expressed against subsidiarity in EU law and, charitably put, its "modesty." 139 It also applies in other contexts such as the liberal-organizational context (where it usually takes the shape of efficiency, though), the federal one and even Catholic social doctrine ${ }^{140}$. In all those contexts, therefore, what does the work in the subsidiarity test is(are) the justification(s) of subsidiarity.

In the assessment of effectiveness, a distinction is often drawn between the individual/smaller/local/internal unit being unable to do something (negative test) and the collective/larger/higher/external unit being able to do so (positive test). In some versions of subsidiarity, both tests are needed as it is the case in EU law (art. 5(3) TEU), while, in most conceptions, the negative test is the sole one that can lead to the reversal of priority. Interestingly, when both positive and negative effectivities are required, the subsidiary test usually turns into a proportionality test. Hence their frequent association in practice (e.g., their juxtaposed treatment in art. 5(4) TEU and in the EU's Protocol on subsidiarity and proportionality). Of course, this may become problematic once the object of subsidiarity itself is to review the proportionality of a given measure as this implies a regress in proportionality. Last but not least, subsidiarity is not a matter of degree and is not incremental. ${ }^{141}$ The positive and negative subsidiarity tests by reference to a proportionality assessment should not therefore be understood so as to indicate the existence of degrees of subsidiarity.

In the human rights context, the prima facie test used for human rights subsidiarity is the effectiveness in the domestic protection of the minimal international standard of human rights. While effectiveness is an aim of international human rights law and a duty of States under the latter, it is difficult to see how it can be used on its own as a test for substantive subsidiarity. The minimal content of a human rights duty and hence the effectiveness of its respect are indeed deeply indeterminate in circumstances of reasonable disagreement. ${ }^{142}$ Thus, deciding on it outside of the democratic process begs the question of the egalitarian justification of human rights and of how to protect it. At the same time, of course, there should be a way of determining a minimal international standard of human rights protection that does not simply amount to giving entirely into domestic evaluations. The latter would undermine the whole complementarity between

\footnotetext{
139 See Barber, "The Limited Modesty of Subsidiarity"; Barroche, Etat, libéralisme et christianisme. 140 See e.g., Finnis, Natural Law and Natural Rights, 146-7.

141 It is not because substantive subsidiarity pertains to the degree of review of an international human rights body or court that subsidiarity itself is a matter of degree, as we will see later. The same may be said about the intensity of the margin of appreciation: its greater or smaller intensity does not imply more or less subsidiarity.

142 See Besson, "Human Rights and Democracy in a Global Context."
} 
international and domestic human rights law. It would also threaten the coherence of international human rights law and hence equality in and before international human rights law.

This may actually explain why other proxies for minimal human rights standards need to be at play in practice, especially in the context of the determination of the scope (and width) of the margin of appreciation of domestic authorities. One may think, for instance, of the European consensus or "converging approach" criterion used by the ECtHR to identify what constitutes minimal human rights protection across the States Parties and before selecting the corresponding degree of scrutiny of a given domestic measure. Regrettably, this is not the sole criterion or test at play in the Court's reasoning when setting the margin of appreciation, however, and its application remains largely unpredictable as a result, as I explained in the first section (II.B.ii.).

Nevertheless, there are ways, I would like to argue, for the European consensus test to be streamlined, generalized and used as a test for substantive subsidiarity, besides the fourth-instance doctrine regarding factual assessments and evidence and the principle of favor regarding what goes beyond the minimal human rights standard, and within the egalitarian limits described in the next section. Referring to the European democratic consensus as the minimal standard of human rights protection corresponds to the democratic justification of human rights subsidiarity. It matches the bottom-up development, alluded to before, of international human rights standards from the transnational human rights practice of democratic States in Europe. ${ }^{143}$ It is the way to secure the democratic legitimacy of international human rights institutions' or courts' review without, however, turning international human rights case-law into an incoherent and hence inegalitarian patchwork of endorsements of individual domestic albeit democratic specifications. ${ }^{144}$

On the proposed interpretation, international human rights courts do not work as ultimate interpreters or umpires. To that extent, they are unlike other international law courts whose interpretative authority derogates from the principle of self-interpretation that prevails in international law. Instead, international human rights courts, like the ECtHR, are facilitators of the self-interpretation of their human rights law by democratic States: they help crystallize and consolidate democratic States' interpretations and practices of human rights and validate the custom stemming from their subsequent practice under human rights treaties. ${ }^{145}$ Once identified and entrenched as international (human rights) law

143 On the transnationality of the sources of human rights law, see Besson, "Human Rights and Constitutional Law: Mutual Validation and Legitimation."

144 Contra: Letsas, "The Margin of Appreciation Revisited"; Gerards, "The European Court of Human Rights and National Courts."

145 This is in line with art. 31(3)(c) of the 1969 Vienna Convention on the Law of Treaties and the so-called evolutive interpretation of treaties based on subsequent practice: ILC, Second Report by Special Rapporteur Georg Nolte (A/CN.4/671, 2014), at 49 ff. See also Ineta Ziemele, "Customary International Law in the Case Law of the European Court of Human Rights," in The Judge and International Custom-Proceedings of the Conference (Strasbourg: Council of Europe Publishing, 2013), 75-83; Paul Mahoney, "The Comparative Method in Judgments of the European Court of Human Rights: Reference Back to National Law," in Comparative Law Before the Courts, ed. Guy 
through the international human rights courts' case-law, the minimal human rights interpretation can then be re-imposed on domestic authorities. ${ }^{146}$ This is what is often referred to as the interpretative authority or erga omnes effect of an international human rights court's decision, an authority very different from an autonomous and ultimate supranational interpretative authority. ${ }^{147}$

Of course, one may object that not all European States are democratic, and that this jeopardizes the democratic argument for the European consensus and its use as a test of substantive subsidiarity. This is a false problem given that all European States Parties to the ECHR have to be democratic as much as they have to respect human rights, and on grounds of the latter actually. ${ }^{148}$ Thus, first of all, their consensus has to be incrementally democratic, just as they incrementally have to protect human rights. Secondly, more specifically, when States have not ensured sufficient democratic deliberation in a given human rights case, their margin of appreciation should be limited or inexistent because the condition for the latter, i.e. domestic reason-giving, is not fulfilled, as I explained before. ${ }^{149}$

Importantly, the existence or absence of European democratic consensus only works as a test for human rights substantive subsidiarity within the egalitarian limits of subsidiarity, i.e., provided non-discrimination rights and the fundamental core of human rights are not at stake. Conversely, and for the same democratic reasons, setting aside the priority of domestic authorities, and especially reducing their margin of appreciation, in cases that pertain to political rights, that are therefore closely related to democracy, requires a strong degree of European democratic consensus or, depending on the cases, may not even be justified in certain rare cases. ${ }^{150}$ This accounts for the few cases I discussed in the first section where the width of the margin of appreciation seems to be decoupled from European consensus in the ECtHR's case-law.

Last but not least, it is worth pausing to discuss a procedural alternative to the regular effectiveness test of human rights subsidiarity that has been suggested by

Canivet, Mads Andenas and Duncan Fairgrieve (London: British Institute of International and Comparative Law, 2004), 135-50.

146 See Besson, "Human Rights Adjudication as Transnational Adjudication"; Besson, "The Sources of International Human Rights Law." On human rights interpretation in general, see e.g., Brigit Schlütter, "Aspects of Human Rights Interpretation by the UN Treaty Bodies," in Human Rights Treaty Bodies: Law and Legitimacy, ed. Hellen Keller and Geir Ulfstein (Cambridge: Cambridge University Press, 2012), 261-319.

147 See Besson, "The 'Erga Omnes' Effect of Judgments of the European Court of Human Rights," on the specificities of that authority and the inapplicability of international and constitutional analogies.

148 Of course, what is constitutive of a democratic State is itself defined by the European consensus crystallized through the ECtHR's case-law. This explains in turn why there is no two-tier system in the ECtHR's case-law on the margin of appreciation depending on how democratic States are. See also Føllesdal, "Appreciating the Margin of Appreciation."

149 See also Føllesdal, "Appreciating the Margin of Appreciation."

150 See e.g., Sitaropoulos and Giakoumopoulos v. Greece, par. 63-5; Podkolzina v. Latvia, ECHR 2002II 443 (CE:ECHR:2002:0409JUD004672699), par. 33; Yumak and Sadak v. Turkey, ECHR 2008III 423 (CE:ECHR:2008:0708JUD001022603), par. 110. See also Samantha Besson and A.-L. Graf-Brugère, "Le droit de vote des expatriés, le consensus européen et la marge d'appréciation des Etats. Un commentaire de l'arrêt Sitaropoulos et Giakoumopoulos c. Grèce," Revue trimestrielle des droits de l'homme 100 (2014): 953-4. 
Olivier De Schutter. He proposes to introduce a "presumption of effectiveness" of human rights protection by domestic authorities that could be rebutted by an international human rights body or court in case of "manifest deficiency." This would be developed mutatis mutandis on the basis of the presumption of equivalence established by the ECtHR in the Bosphorus case and in favor of the EU. ${ }^{151}$

Besides the immediate institutional benefits for the backlog of the ECtHR, such a presumption and its rebuttal would seem to be procedurally more determinate and hence predictable than the current subsidiarity test of effectiveness. Of course, the manifest deficiencies in human rights protection would still have to be established and this could be regarded as just as indeterminate. There is another more important objection, however. The presumption of equivalence was introduced to take into account ECHR States Parties' membership in international organizations and the latter's concurrent human rights regimes ${ }^{152}$ and hence in order to ease their potential conflicts. By contrast, there is no "equivalence" to look for between domestic and international human rights law, because, as I explained before, they are not concurrent but complementary in functions. This lack of equivalence also extends therefore to their corresponding judicial institutions' powers to review: there is simply no ground for a duty of equivalence and hence for a presumption of equivalence between them. Both domestic authorities and international human rights bodies should review: their review is complementary and not alternative. International human rights review is not to be dispensed through a presumption, as a result.

\section{vi. Limits of Subsidiarity}

The limits of subsidiarity can be of different kinds. They actually vary a lot from one context to the other, even though the different limits need not be mutually exclusive and may overlap.

The first limit on subsidiarity one could mention is the existence of an exclusive or pre-allocated competence. This is the case in the federal context or in EU law (art. 5(3) TEU). A second limit pertains to justice. This is a limitation familiar from the Catholic doctrine of subsidiarity. Yet another kind of limits stems from the justification(s) chosen for subsidiarity. For democracy, this would be equality. This is also familiar in the federal context where subsidiarity is limited by reference to the protection of equality of the federal units.

In international human rights law, the limits to subsidiarity are those inherent to democracy itself, i.e., equality-based limitations. The constitutive mutuality

151 See Olivier de Schutter, "The Two Lives of Bosphorus: Redefining the Relationships between the European Court of Human Rights and the Parties to the Convention," Journal européen des droits de l'homme / European Journal of Human Rights 4 (2013): 584-524. See also Bosphorus Hava Yollar1 Turizm ve Ticaret Anonim Şirketi v. Ireland, ECHR 2005-VI 107 (CE:ECHR:2005:0630 JUD004503698).

152 In the EU, for Bosphorus v. Ireland, in NATO for Gasparini v. Italy and Belgium, App no 10750/ 03 (ECtHR, Decision of 12 May 2009, CE:ECHR:2009:0512DEC001075003) and in the UN, for Al-Dulimi and Montana Management Inc. v. Switzerland, App no 5809/08 (ECtHR, 26 November 2013, CE:ECHR:2013:1126JUD000580908). 
between human rights and equality explains how democracy can justify equality-based limitations on human rights, while the latter can in turn justify equality-based limitations on democracy. What this means for the limits on human rights subsidiarity is that individual equality constitutes its limit. This can take the shape of non-discrimination rights, but also, more generally, of the prohibition of the erosion of the so-called inner or fundamental core of a given human right and hence of the basic equality of its right-holder. This is confirmed in the international human rights practice, and in particular by the ECtHR's caselaw, as I explained before.

\section{vii. Review of Subsidiarity}

The mechanisms for the review of subsidiarity can be of different kinds. They actually vary a lot from one context to the other, even though the different review mechanisms need not be mutually exclusive and may overlap.

The primary and most common form of review of subsidiarity is centralized. It can be vested in a judicial entity in the central unit, but also in legislative and executive ones or in all of them if the review is diffuse. This is the case in the EU where the main subsidiarity review has to take place at the Commission, but also at every step of the EU law-making process, i.e. in the Parliament and the Council as well. Respect for subsidiarity may also be reviewed by the CJEU. A second form of review of subsidiarity is decentralized and extends the possibility of review to individual/local/smaller/internal units. This is the case in the EU where, since the Lisbon Treaty, national parliaments, whether on their own, through their Member States or the Committee of Regions, may review the respect of the subsidiarity principle in EU law (see art. 263 par. 3 Treaty on the Functioning of the EU [TFEU] and art. 8 EU Protocol on subsidiarity and proportionality).

Subsidiarity review often implies reviewing a proportionality test. As I explained before, especially when the assessment of both positive and negative effectiveness is required, the subsidiary test usually implies a proportionality test. Of course, this may become problematic when the object of subsidiarity is to review the proportionality of a given measure, for the review of subsidiarity becomes not only a review of a review, but also a proportionality-based review of a proportionality-based review. Sometimes, it may even pertain to yet another proportionality-based review domestically.

In the human rights context, the review of subsidiarity is not usually institutionalized to the extent that international human rights bodies or courts are not submitted to further review with respect to subsidiarity. Interestingly, the entrenchment of subsidiarity into the Preamble of the Convention by Protocol 15 is interpreted by some as a signal of the appropriation of subsidiarity by States and potentially as enabling the review by the ECtHR of human rights subsidiarity in the future. ${ }^{153}$ Some have even argued that the facilitation of Grand Chamber

153 See e.g., Sudre, "La subsidiarité, 'nouvelle frontière' de la Cour européenne des droits de l'homme"; Sudre, "Le recadrage de l'office du juge européen"; Tavernier, "La constitutionnalisation de la marge d'appréciation." Contra: Spielmann, "Whither the Margin of Appreciation?”, who argues for the status quo after Protocol 15. 
referrals by Protocol 15 ECHR (art. 3), once it is in force, could be a way of initiating an indirect review of human rights subsidiarity by the Court in its other formations. ${ }^{154}$

What would make a review of human rights subsidiarity very difficult in any case is that it would amount to a review of a review. Worse, it may even amount to a review by the ECtHR of its own review of a review by a domestic court when what is at stake is a human rights' restriction. There is also an identity issue for it is difficult to see how the very same court could be the reviewer of its own review and, worse, of its own interpretation of what the principle of subsidiarity on which that review is based amounts to.

\section{Human Rights Subsidiarity in Focus}

The outcome of this exercise in comparative subsidiarity law has been that human rights subsidiarity differs substantially from other conceptions of subsidiarity, despite sharing key features of subsidiarity, and in particular its two-step functioning and its two-party structure. It implies indeed, first, the priority not only of the domestic application and interpretation of international human rights law but also of its review and enables, second, the complementing of that domestic review through international human rights review in the absence of effective protection of the international minimal human rights standard in domestic law.

There are two implications of the specificity of human rights subsidiarity for how we should interpret the concept of human rights subsidiarity in the future: one negative and the other positive.

First of all, human rights subsidiarity should not be too quickly forced into the boxes of other conceptions of subsidiarity that have different subjects, objects, functions, tests, justifications and limits. This is in particular the case for analogies with EU law subsidiarity, and the margin of appreciation of EU Member States before the CJEU, ${ }^{155}$ or with federalist subsidiarity, and the indirect rule by federal entities. ${ }^{156}$ Unlike human rights subsidiarity, both of them pertain to sovereign or autonomous political entities and legal orders. Moreover, they concern general competences and not (duties or powers to) review. Finally, they pertain to the competitive allocation or exercise of these competences rather than the complementary sequencing of a power to review.

\footnotetext{
154 See e.g., the contrasting decisions on the European consensus and the width of the margin of appreciation by the Chamber and Grand Chamber in Sitaropoulos v. Greece (Chamber judgment: Sitaropoulos and Others v. Greece, App no 42202/07 [ECtHR, 8 July 2010, CE:ECHR:2010: 0708JUD004220207]; Grand Chamber judgment: see above Sitaropoulos and Giakoumopoulos v. Greece) and in Lautsi v. Italy (Chamber judgment: Lautsi v. Italy, App no 30814/06 [ECtHR, 3 November 2009, CE:ECHR:2009:1103JUD003081406]; Grand Chamber judgment: Lautsi v. Italy, ECHR 2011-III 61 [CE:ECHR:2011:0318JUD003081406]). See Sudre, "La subsidiarité, 'nouvelle frontière' de la Cour européenne des droits de l'homme."

155 See e.g., Fabbrini, "The Margin of Appreciation and the Principle of Subsidiarity: A Comparison."

156 See e.g., Cassese, "Ruling Indirectly—Judicial Subsidiarity in the ECHR."
} 
A second implication, more positive, is that the egalitarian and hence democratic justification of human rights subsidiarity should be developed further as tool of interpretation of the various dimensions of human rights subsidiarity in practice. This would help devise a clearer test of substantive subsidiarity in particular, but also clearer limits to subsidiarity in practice along the lines of what I have proposed before. ${ }^{157}$ Of course, the ECtHR's reasoning about the scope, width and limits of the margin of appreciation of States, and especially the European consensus test, has lacked coherence to this day. Once clarity has been gained about human rights subsidiarity, however, and once the democratic justification of the European consensus test for the identification of the minimal European human rights standard and hence as a substantive subsidiarity test has been provided, a lot of the confusions that prevail in the area could be more easily dismissed.

This is important for human rights practice too as recent developments indicate what one may regard as the growing "subsidiarity of subsidiarity" in international human rights reasoning. ${ }^{158}$ In the ECtHR's case-law, for instance, the focus seems to have shifted entirely onto the primarity of domestic authorities' duties and responsibilities for human rights protection and especially on the pre-emptive determination thereof. ${ }^{159}$ This goes further than merely focusing on the negative aspect of subsidiarity and one of its two "sides" before turning to the other one, i.e. the Court's review power, its intensity and scope. It actually transforms subsidiarity into an instrument for the pre-determination of the content of States' human rights duties. One should mention three examples of this trend towards the "subsidiarization" of subsidiarity, all three being ironically explicitly grounded in subsidiarity: first of all, the increasing proceduralization and hence abstraction of the ECtHR's review ${ }^{160}$; secondly, its future preventive control once Protocol 16 ECHR enters into force and the advisory opinion procedure applies to the States Parties that have ratified it ${ }^{161}$; and, finally, the development of remedial control by the ECtHR as in the prescription of individual measures. These developments are worrying, first of all, because the so-called primarity of human rights duties, and the primary responsibility of domestic authorities, exist independently from the principle of subsidiarity: they amount to the latter's background and not to one of its implications. Secondly, human rights subsidiarity pertains to the ex post review of human rights implementation, and not to the ex ante specification of human rights duties by an international human rights body or court.

Another related cause of concern is that many authors, disappointed by the complexity of human rights subsidiarity, have turned to alternative principles. The

\footnotetext{
157 See also Føllesdal, "Appreciating the Margin of Appreciation."

158 For a complete argument, see Samantha Besson, "L'évolution du contrôle européen: une subsidiarité toujours plus subsidiaire," in L'avenir de la Cour européenne des droits de l'homme (Paris: Pédone, forthcoming 2016).

159 See e.g., "ECtHR Background paper, Subsidiarity: A Two-Sided Coin?" and the focus of the 2015 ECtHR Seminar where half of the discussions pertained to the responsibilities of States Parties. See also Tulkens, "Conclusions générales."

160 See also Dubout, "La procéduralisation des droits."

161 See e.g., Gerards, "Advisory Opinions, Preliminary Rulings and the New Protocol 16 to the European Convention on Human Rights."
} 
risk is that they are thereby re-inventing the wheel of subsidiarity albeit under another name. One may mention, for instance, the fast developing references to "embeddedness,"162 "partnership"163 or "judicial dialogue"164 in ECHR scholarship. While it is correct to say that judicial dialogue between domestic courts and the ECtHR has contributed to the quality of the Court's human rights reasoning, that dialogue should take place in the context of an individual application pending before the ECtHR and not early on before the domestic court has even had a chance to decide and hence to give reasons. Judicial dialogue promotes human rights subsidiarity, but should not be invoked to dispense with it altogether, preempt the reason-giving of domestic judges and replace it by that of the ECtHR itself.

\section{Conclusions}

This article aimed at understanding what is subsidiary about human rights. It started from the practice of human rights subsidiarity and identified three types of subsidiarity (procedural, substantive and remedial) therein. It then proceeded with a comparative-normative discussion of the different dimensions of subsidiarity encountered in the human rights context and, on that basis, proposed a differentiated interpretation of human rights subsidiarity.

The main thrust of the argument has been that the concept of subsidiarity is at play in international human rights law with its two-step functioning and two-parties structure, but that it is very different from the other conceptions of subsidiarity we know of. In a nutshell, the main specificities of human rights subsidiarity that have been established are the following.

First of all, its context is not that of a polity or autonomous legal order, but the political or judicial review of domestic human rights implementation by an international body or court. Second, its subjects are domestic authorities (including judicial ones), on the one hand, and international human rights bodies or courts, on the other, and neither States or infra-national and international political entities, nor individuals or groups of individuals. Third, its object is an international judicial or institutional monitoring or reviewing competence, on the one hand, and a domestic positive duty to respect and protect human rights that includes a duty to acquire a judicial competence of decision and review, on the other, and not either competences or duties to review alone. Fourth, its function is sequencing the complementary exercise of review (procedural subsidiarity) or its intensity (substantive subsidiarity) between domestic authorities and international human rights bodies or courts, and not allocating competing competences, or the exercise thereof, to either one or the other of the subjects of subsidiarity. In short, human rights subsidiarity amounts to the complementarity of review powers and

162 See e.g., Helfer, "Redesigning the European Court of Human Rights."

163 See e.g., Gerards, "The European Court of Human Rights and National Courts."

164 See e.g., Dean Spielmann, "Whither Judicial Dialogue?-Sir Thomas More Lecture," Lincoln's Inn, London, 12 October 2015. http://www.echr.coe.int/Documents/Speech_20151012_Spiel mann_Sir_Thomas_More_Lecture.pdf. 
responsibilities, as opposed to the competition of review powers. Fifth, the justification of human rights subsidiarity is democratic (and, accordingly, epistemic in some cases of reasonable disagreement), but not in the way subsidiarity is usually justified in a democratic polity of polities. There is indeed only one democratic polity at stake in human rights subsidiarity: the domestic one. Human rights subsidiarity's democratic justification actually goes back to equality and the egalitarian dimension of human rights themselves. Sixth, the test of human rights subsidiarity is the effectiveness of the domestic protection of the international minimal human rights standard. The test for this, in circumstances of widespread and persistent reasonable disagreement about the effectiveness of human rights, is the existence or absence of a democratic transnational consensus about a specific human right and its duties. Seventh, the limits on human rights subsidiarity are egalitarian and democratic and reflect its justification. They consist in, more specifically, non-discrimination rights and the basic equality of every human right-holder. Finally, the review of human rights subsidiarity has not been institutionalized yet unlike what happens in other contexts. It would be fraught with difficulties in any case for it implies a review of a review (of a review) and, further, one that would have to be conducted by the same international human rights body or court.

Understanding the specificities of human rights subsidiarity is particularly important as current interpretations of human rights subsidiarity tend to make it more and more subsidiary. Human rights subsidiarity has been made subsidiary, first of all, in conceptual terms. This is due to common theoretical conflations with other conceptions of subsidiarity that are remote from what justifies human rights subsidiarity in the first place: the inherent egalitarian and hence democratic dimension of human rights. We should be cautious, as a result, about quick analogies with EU law or federal conceptions of subsidiarity, but also with the Catholic social doctrine of subsidiarity. The second context of subsidiarization of human rights subsidiarity has occurred in practice and, ironically, in the name of subsidiarity. While it is true that the complementing of domestic authorities' reviewing is the second prong of the (human rights) subsidiarity principle and that it may and should take place in certain cases, international human rights bodies and courts have been turning that complementing into the focal point of subsidiarity. So-doing, they are paradoxically transforming subsidiarity into a tool to pre-determine the human rights duties and responsibilities of States and are, as a result, pre-empting its function and justification entirely.

Once the focus is back on human rights subsidiarity for what it is, progress could be made with respect to how it is used in human rights reasoning. From a normative perspective, tying human rights subsidiarity back to its egalitarian and democratic justification could help specifying and justifying its tests and limitations along the lines I have proposed. More practically, this could help addressing important practical challenges international human rights law is currently facing, and in particular in the context of the reform of the ECHR system. 